\title{
Enhancement of adoptive $T$ cell transfer with single low dose pretreatment of doxorubicin or paclitaxel in mice
}

\author{
Fei-Ting Hsu ${ }^{1,2,3, *}$, Tzu-Chun Chen ${ }^{1,4, *}$, Hui-Yen Chuang ${ }^{1}$, Ya-Fang Chang ${ }^{1}$ and \\ Jeng-Jong Hwang ${ }^{1,5}$ \\ ${ }^{1}$ Department of Biomedical Imaging and Radiological Sciences, National Yang-Ming University, Taipei, Taiwan \\ 2 Department of Medical Imaging, Taipei Medical University Hospital, Taipei, Taiwan \\ ${ }^{3}$ Translational Imaging Research Center, College of Medicine, Taipei Medical University, Taipei, Taiwan \\ ${ }^{4}$ Department of Radiation Oncology, Chang Gung Memorial Hospital, Linkou, Taiwan \\ ${ }^{5}$ Biophotonics and Molecular Imaging Research Center (BMIRC), National Yang-Ming University, Taipei, Taiwan \\ * These authors have contributed equally in this work \\ Correspondence to: Jeng-Jong Hwang, email: jjhwang@ym.edu.tw
}

Keywords: adoptive T cell transfer, bioluminescent imaging, doxorubicin, NF-KB, paclitaxel, Immunology and Microbiology Section, Immune response, Immunity

Received: August 30, 2015

Accepted: November 25, 2015

Published: December 16, 2015

\section{ABSTRACT}

Ex vivo expansion of $\mathrm{CDB}^{+} \mathrm{T}$-cells has been a hindrance for the success of adoptive $\mathrm{T}$ cell transfer in clinic. Currently, preconditioning with chemotherapy is used to modulate the patient immunity before ACT, however, the tumor microenvironment beneficial for transferring $T$ cells may also be damaged. Here preconditioning with single low dose of doxorubicin or paclitaxel combined with fewer CD8 ${ }^{+} \mathrm{T}^{-}$-cells was investigated to verify whether the same therapeutic efficacy of ACT could be achieved. An E.G7/OT1 animal model that involved adoptive transfer of OVA-specific CD8 ${ }^{+}$ T-cells transduced with a granzyme B promoter-driven firefly luciferase and tomato fluorescent fusion reporter gene was used to evaluate this strategy. The result showed that $\mathrm{CD8}^{+} \mathrm{T}$-cells were activated and sustained longer in mice pretreated with one low-dose Dox or Tax. Enhanced therapeutic efficacy was found in Dox or Tax combined with $2 \times 10^{6} \mathrm{CDB}^{+} \mathrm{T}$-cells and achieved the same level of tumor growth inhibition as that of $5 \times 10^{6} \mathrm{CD8}^{+} \mathrm{T}$-cells group. Notably, reduced numbers of Tregs and myeloid derived suppressor cells were shown in combination groups. By contrast, the number of tumor-infiltrating cytotoxic T lymphocytes and IL-12 were increased. The NF-KB activity and immunosuppressive factors such as TGF- $\beta$, IDO, CCL2, VEGF, CCL22, COX-2 and IL-10 were suppressed. This study demonstrates that preconditioning with single low dose Dox or Tax and combined with two fifth of the original $\mathrm{CD}^{+} \mathrm{T}$-cells could improve the tumor microenvironment via suppression of NF-KB and its related immunosuppressors, and activate more $\mathrm{CDB}^{+} \mathrm{T}$-cells which also stay longer.

\section{INTRODUCTION}

Adoptive T cell transfer (ACT) using tumor-specific CD8+ T-cells are selected with specific tumor-associated antigens, expanded and activated with cytokines including interleukin (IL)-2, -7 and -15 , then transfused back to the patient $[1,2]$. However, ACT is currently not applied widely in clinic since the ex vivo large-scale expansion of $\mathrm{T}$ cells is inefficient and costly [3, 4]. Moreover, cancer cells may evolve and exert capabilities against attacks from transferred CD8+ T-cells, i.e. cytotoxic T lymphocytes, CTLs [5]. Hence, it is imperative to find a strategy to enhance the functions while reduce the required numbers of transferred CD8+ T-cells for ACT.

Cancer cells keep evolving during progression and could escape from immune surveillance. Immunosuppressive cytokines such as transforming growth factor- $\beta$ (TGF- $\beta$ ) could inhibit the activation of CD8+ T-cells, which play the key role in hindrance of cancer elimination by ACT [6]. TGF- $\beta$ also decreases expressions of anti-tumor cytokines including interferon gamma (IFN- $\gamma$ ) and interleukin-12 (IL-12), and further 
restrains proliferation and differentiation of $\mathrm{T}$ cells $[7$, 8]. The secretions of IFN- $\gamma$ and IL- 12 are also inhibited by IL-10 to impair the function of CD8+ T-cells [9]. Moreover, secretion of TGF- $\beta$, IL-10, chemokine (CC motif) ligand 22 (CCL22), cyclooxygenase-2 (COX2 ), vascular endothelial growth factor (VEGF) and chemokine (C-C motif) ligand 2 (CCL2) will recruit immune regulatory cells such as regulatory $\mathrm{T}$ cells (Tregs) and myeloid derived suppressor cells (MDSCs) into tumor lesions [10-12]. Accumulation of these cells will suppress the functions and proliferation of $\mathrm{CD} 8+\mathrm{T}$-cells [13]. Furthermore, IDO expressed by cancer cells converts tryptophan into kynurenine which inhibits the proliferation of $T$ cells and hinder the conversion of Tregs into $T_{H} 17$ $[14,15]$. Expressions of CCL2, COX-2 and VEGF are also related to invasion, metastasis and angiogenesis [16-18].

Nuclear factor kappa-light-chain-enhancer of activated $\mathrm{B}$ cells (NF-kB), a transcription factor, has been shown to play a key hub for immune regulations [19-21]. NF- $\mathrm{KB}$ may promote the tumor formation and progression through up-regulation of its downstream effectors including TGF- $\beta$, IL-10, CCL2, COX-2, VEGF and CCL22 [22, 23]. Cancer cells could escape from the immune surveillance with expressions of these proteins. Thus targeting NF- $\mathrm{kB}$ may be an achievable strategy to modify the immunosuppression of tumor microenvironment [24]. Some chemotherapeutic or targeted drugs have been proposed to trigger antitumor immunity other than eliminate cancer cells directly [25]. Our recent findings suggest that serial low doses of curcumin or sorafenib combined with ACT exhibit better tumor inhibition [26, 27]. However, it has been reported that Dox and Tax may induce the activation of NF- $\mathrm{KB}$ under the administration of clinical dosage [2830]. Thus, preconditioning using optimal dosage of Dox or Tax to avoid activating NF- $\mathrm{KB}$ and its downstream effectors is critical for the success of ACT. Here we aimed to investigate whether single low dose of Dox or Tax prior to ACT could augment the treatment outcome and the related underlying mechanisms. The $p G B e L T$ reporter system established by Patel et al. to monitor the activation of transferred CD8+ T-cells for ACT in E.G7/OT-1 mouse model was used [31]. Immunosuppressive cytokines and other immune cells such as Tregs and MDSCs were also determined.

\section{RESULTS}

\section{Immunosuppressive factors are suppressed by one low-dose Dox or Tax through reducing NF- $\kappa B$ activity in E.G7 cells}

The survivals of E.G7 mouse lymphoma cells treated with different concentrations of Dox, Tax and QNZ, a NF- $\kappa \mathrm{B}$ inhibitor, respectively, were shown in Supplementary Figure 1A-1C. The expressions of TGF- $\beta$, CCL2, VEGF, CCL22, COX-2 and IL-10 in E.G7 cells were significantly suppressed by $0.4 \mu \mathrm{M}$ Dox, $12.5 \mathrm{nM}$ Tax and $5 \mathrm{nM}$ QNZ (Figure 1A). To mimic the tumor microenvironment, $500 \mathrm{U} / \mathrm{mL}$ IFN- $\gamma$ was added into the cultured medium to stimulate the expression of IDO, an enzyme often overexpressed in the tumor microenvironment. IDO was highly expressed after IFN- $\gamma$ stimulation, but was suppressed by Dox $(0.4 \mu \mathrm{M})$, Tax $(12.5 \mathrm{nM})$ and QNZ $(5 \mathrm{nM})$, respectively (Figure 1B). Notably, significant inhibitions of NF- $\mathrm{kB} / \mathrm{DNA}$ binding activity by Dox and Tax were also found (Figure 1C).

Enhancement of CD8+ T-cells activation and
migration by one low-dose Dox or Tax is through
downregulation of NF- $\kappa$ B activation in E.G7 cells

The percentages of intracellular IFN- $\gamma$-, IL-2and tomato fluorescence-positive CD8 + T-cells were increased significantly in low-dose Dox, Tax and QNZpretreated groups compared with that of vehicle (Figure 2A-2C), suggested that low-dose Dox, Tax and QNZ could enhance the activation of CD8+ T-cells. The transwell assay also showed that the numbers of migrated $\mathrm{T}$ cells were increased by the treatments of low-dose Dox, Tax and QNZ (Figure 2D).

\section{Single low dose Dox or Tax suppresses expressions of immunosuppressive factors through inhibition of $\mathrm{NF}-\kappa \mathrm{B}$ activity}

E.G7 tumor-bearing mice were established on day -7 and treated with or without single low doses of Dox ( 1 and $4 \mathrm{mg} / \mathrm{kg}$ ) or Tax (5 and $10 \mathrm{mg} / \mathrm{kg}$ ) on day -1 , followed by ACT on day 0 , and mice were sacrificed on day3. The expressions of TGF- $\beta$, IDO, CCL2, VEGF, CCL22, COX-2 and IL-10 in tumors were significantly reduced in Dox- and Tax-treated groups (Figures 3A and 3B). The results were similar with those found in vitro. Notably, these immunosuppressive factors were decreased starting from day 1 post single low dose Dox and Tax treatment, respectively, as shown in Supplementary Figure $2 \mathrm{~A}$ and $2 \mathrm{~B}$. The NF- $\mathrm{kB} / \mathrm{DNA}$ binding activity in tumors was suppressed in both Dox- and Tax-treated groups as demonstrated with EMSA (Figure 3C).

\section{Single low-dose Dox or Tax reduces the percentages of regulatory $T$ cells and myeloid derived suppressor cells in mice}

The percentages of Tregs $\left(\mathrm{CD} 4{ }^{+} \mathrm{CD} 25^{+} \mathrm{FoxP}^{+}\right)$and MDSCs $\left(\mathrm{CD} 1 \mathrm{~b}^{+} \mathrm{Gr} 1^{+}\right)$in TDLN/spleen and bone marrow/ spleen, respectively, were significantly decreased after 


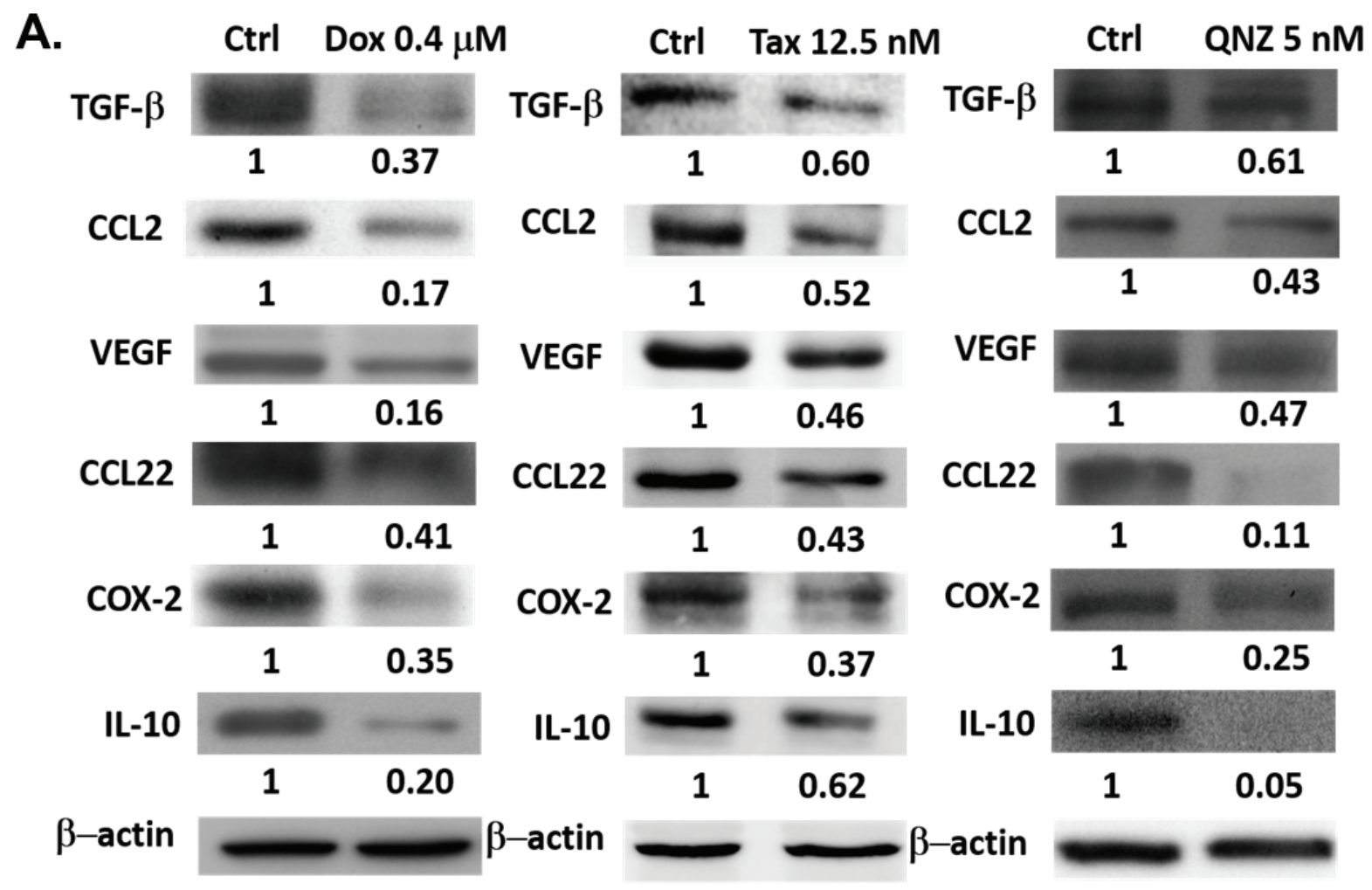

B.
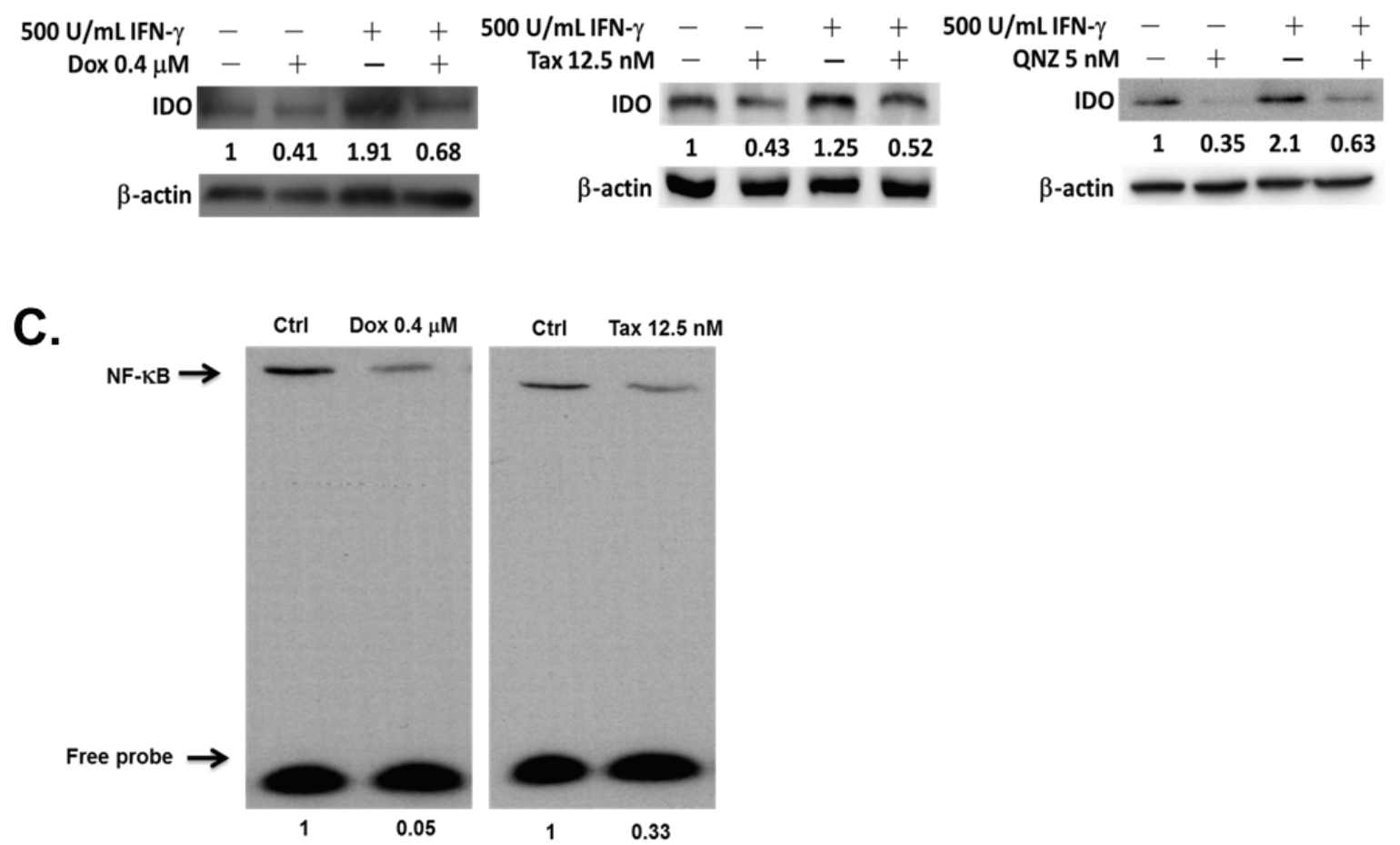

Figure 1: Expressions of immunosuppressive factors are decreased by one low-dose Dox or Tax via inhibition of NF-kB pathway. A. Proteins were extracted from E.G7 cells treated with $0.4 \mu \mathrm{M}$ Dox, $12.5 \mathrm{nM}$ Tax and $5 \mathrm{nM}$ QNZ (NF-kB inhibitor, QNZ), respectively, for 24 hours, and assayed by Western blot. Expressions of immunosuppressive factors were decreased in a dose-dependent manner. B. Both $0.4 \mu \mathrm{M}$ Dox and $12.5 \mathrm{nM}$ Tax could inhibit the expression of exogenous IDO stimulated by IFN- $\gamma$. $5 \mathrm{nM}$ QNZ was the positive control. C. NF-kB activities in E.G7 cells treated with $0.4 \mu \mathrm{M}$ Dox and $12.5 \mathrm{nM}$ Tax, respectively, for 24 hours were significantly inhibited according to EMSA assay. 
A.
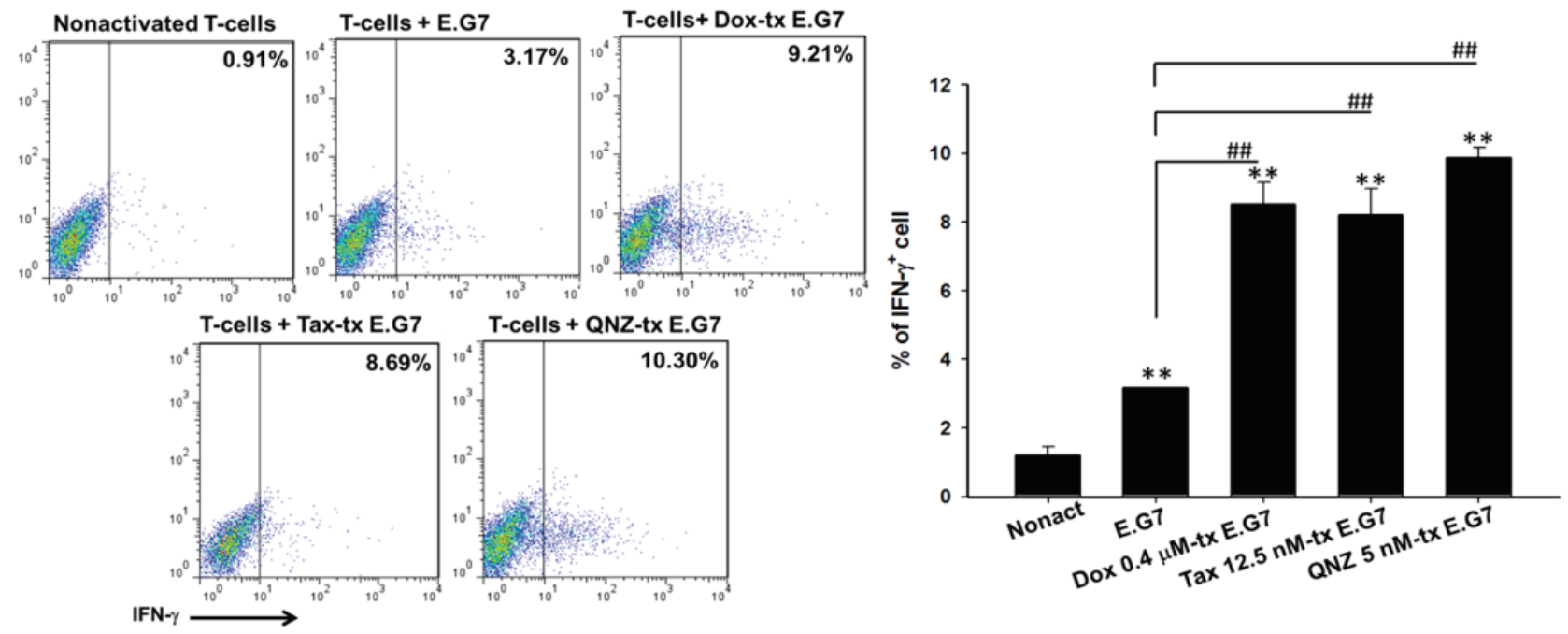

B.
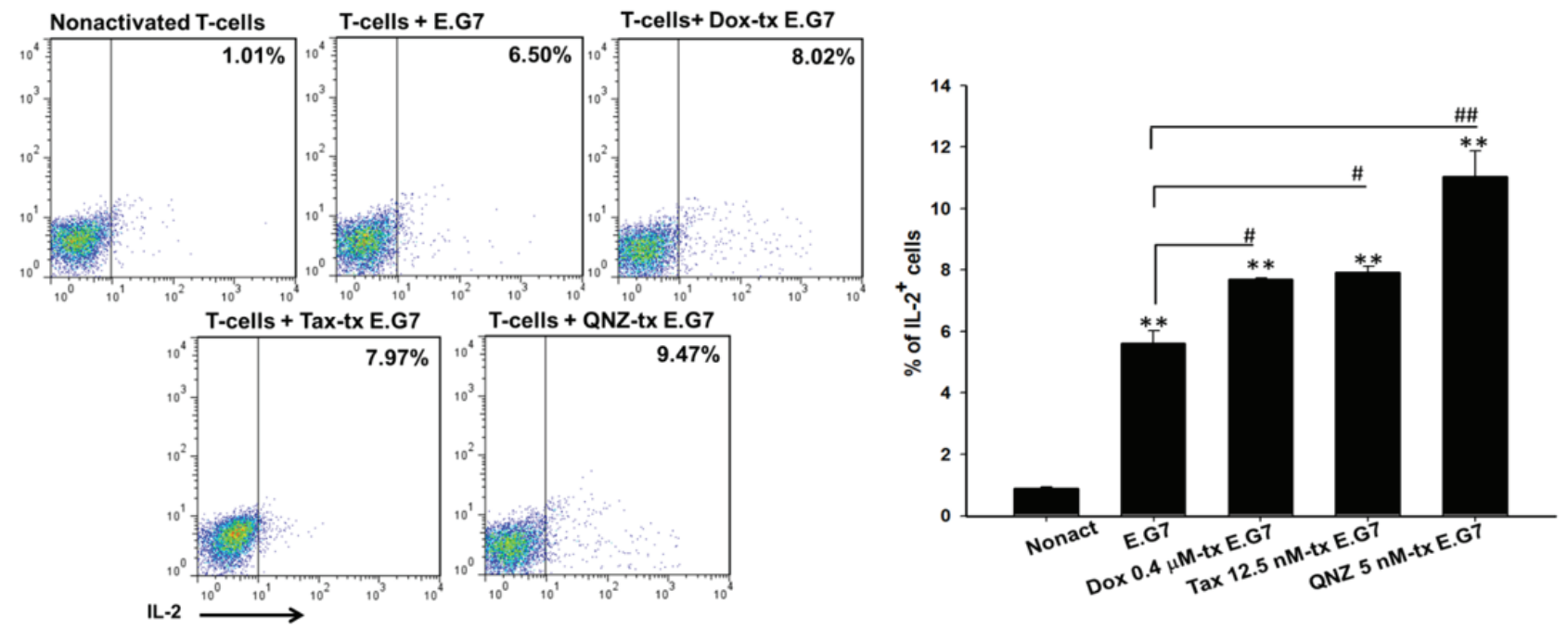

\section{C.}
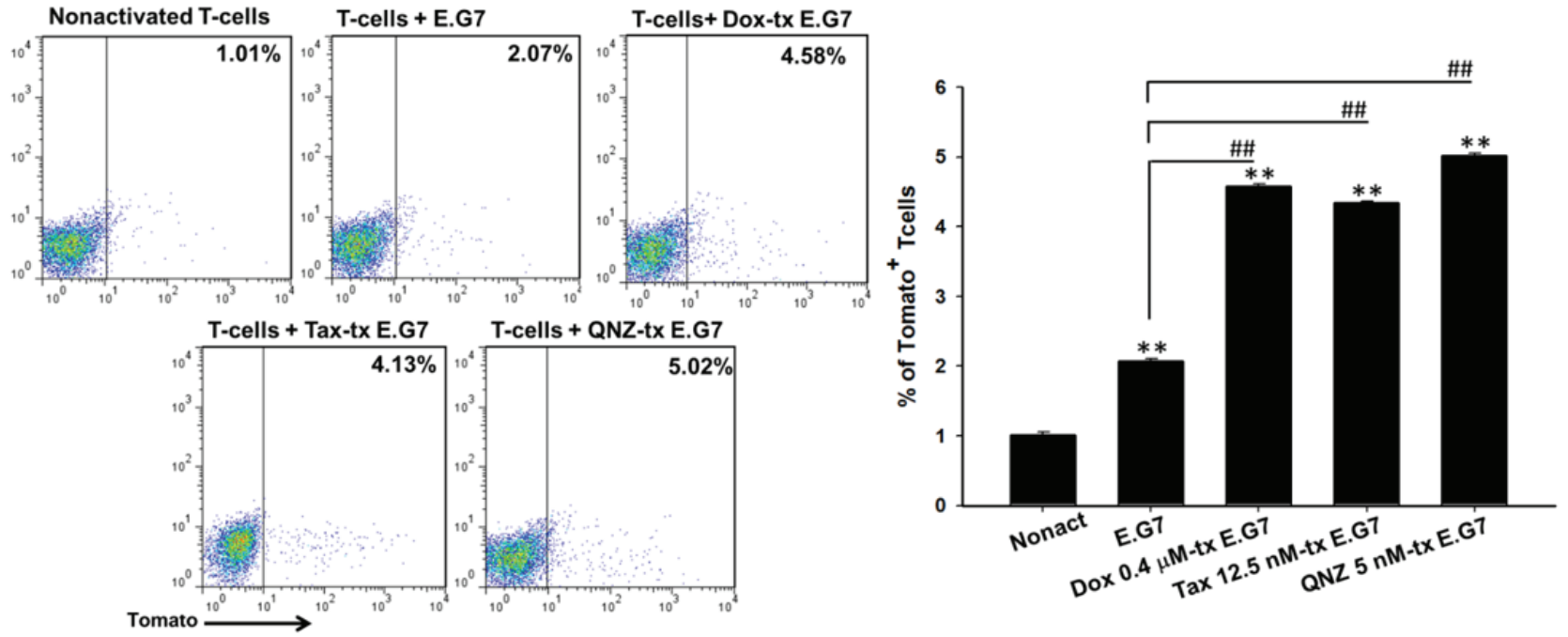

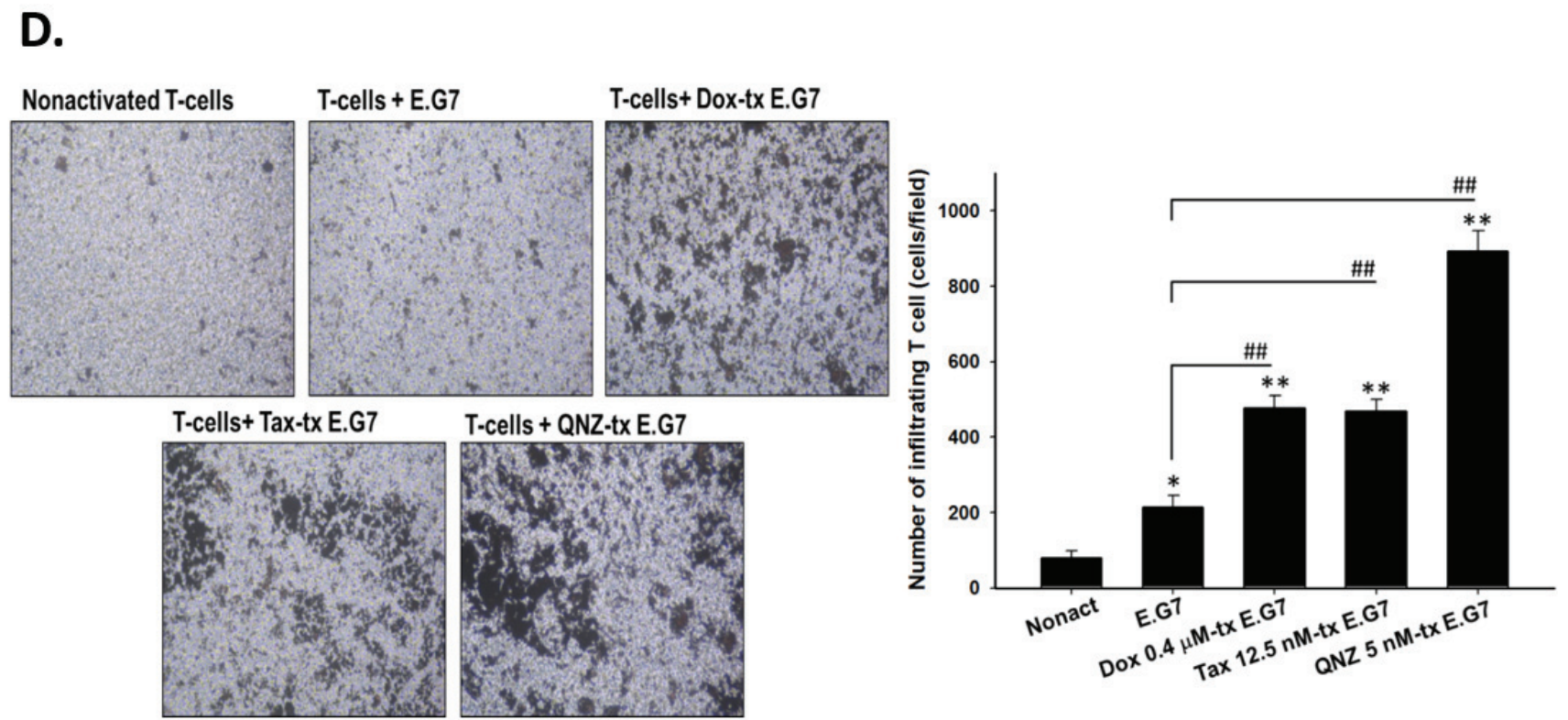

Figure 2: Low-dose Dox or Tax enhanced activation and migration of CD8+ T-cells through inhibition of NF- $\mathrm{B}$. A.B. Isolated CD8+ T-cells were co-cultured with E.G7 cells pretreated with $0.4 \mu \mathrm{M}$ Dox, $12.5 \mathrm{nM}$ Tax and $5 \mathrm{nM}$ QNZ, respectively, at the effector-to-target ratio 25. Intracellular IFN- $\gamma$ and IL-2 were significantly increased in the Dox, Tax and QNZ-pretreated groups compared with the untreated group. C. Expression of tomato fluorescent protein in $p G B e L T$-transduced CD8+ T-cells was evaluated, and was found significantly increased in all pretreated groups. D. Migratory CD8+ T-cells were remarkably increased in the groups pretreated with lowdose Dox, Tax or QNZ. $\left(* p<0.05, * * p<0.01,{ }^{*}\right.$ compared with that of non-activated group; ${ }^{*}$ compared with that of untreated E.G7 group)

single low-dose Dox or Tax treatment (Figures 3D and 3E). Significant decreases of these immunosuppressors were also found on day 1 post one low-dose Dox or Tax treatment as shown in Supplementary Figure 2C and 2D. On the contrary, the levels of serum IL-12 were increased on day 3 post one low-dose Dox or Tax treatment determined with ELISA (Figure 3F).

\section{Therapeutic efficacy of ACT is improved by pretreatment with single low dose Dox or Tax}

Since we have found that $70 \mathrm{mg} / \mathrm{kg} / \mathrm{d}$ curcumin combined with $5 \times 10^{6}$ OT- 1 CD8+ T-cells could completely inhibit the growth of E.G7 tumor, $5 \times 10^{6}$ OT- 1 CD8+ T-cells were also used here [27]. E.G7 tumorbearing mice were randomly separated into seven groups ( $n=6$ per group) as described in the method when the average tumor size reached about $100 \mathrm{~mm}^{3}$. Single low dose Dox $(4 \mathrm{mg} / \mathrm{kg})$ or Tax $(10 \mathrm{mg} / \mathrm{kg})$ was injected intraperitoneally prior to ACT, and was designated as day -1 . The entire experimental protocol was shown in Figure 4A. Significant tumor shrinkage was found in two combination groups (i.e. Dox $+2 \mathrm{~T}$ and $\mathrm{Tax}+2 \mathrm{~T}$ ) on day 3 post ACT compared with that of the control group (Figure 4B). Notably, the tumor growth inhibition of combination groups were the same compared with that of $5 \mathrm{~T}$ group (T stands for $1 \times 10^{6}$ OT-1 CD8+ T-cells). No significant body weight change was found in all groups throughout the experiment (Figure 4C).
A granzyme B promoter-driven firefly luciferase and tomato fluorescent fusion reporter gene ( $p G B e L T)$ system was used to monitor the activation and distribution of transferred OT-1 CD8+ T-cells. The baseline images were acquired at 4 hours after ACT, and the activation of OT- 1 CD8+ T-cells were monitored by BLI at designated time points as shown in Figure 4D. The signals emitted from tumors were increased and peaked on day 5 post ACT for both combination groups, and were significantly higher than those of $5 \mathrm{~T}$ and $2 \mathrm{~T}$ groups, respectively (Figure $4 \mathrm{E})$. The levels of cleaved caspase-3 in tumors were most increased, by contrast, IDOs were severely decreased on day 3 post ACT in two combination groups assayed with Western blot (Figure 4F).

\section{Ratios of tumor-infiltrating $\mathrm{CD4}^{+} \mathrm{FoxP3}^{+}$Tregs/ $\mathrm{CD8}^{+} \mathrm{CTLs}$ are decreased in experimental groups}

From immunohistochemical analysis, tumorinfiltrating $\mathrm{CD}^{+} \mathrm{FoxP}^{+}$Tregs were decreased while tumor-infiltrating CTLs were increased in all experimental groups especially in combination groups compared with those of the control group (Figures 5A and 5B). Accordingly, ratios of $\mathrm{CD}^{+}{ }^{+} \mathrm{FoxP}^{+}{ }^{+}$Tregs/ $\mathrm{CD} 8^{+} \mathrm{CTLs}$ were significantly decreased in two combination groups compared with that of the control or drug alone (Figure $5 \mathrm{C})$. 

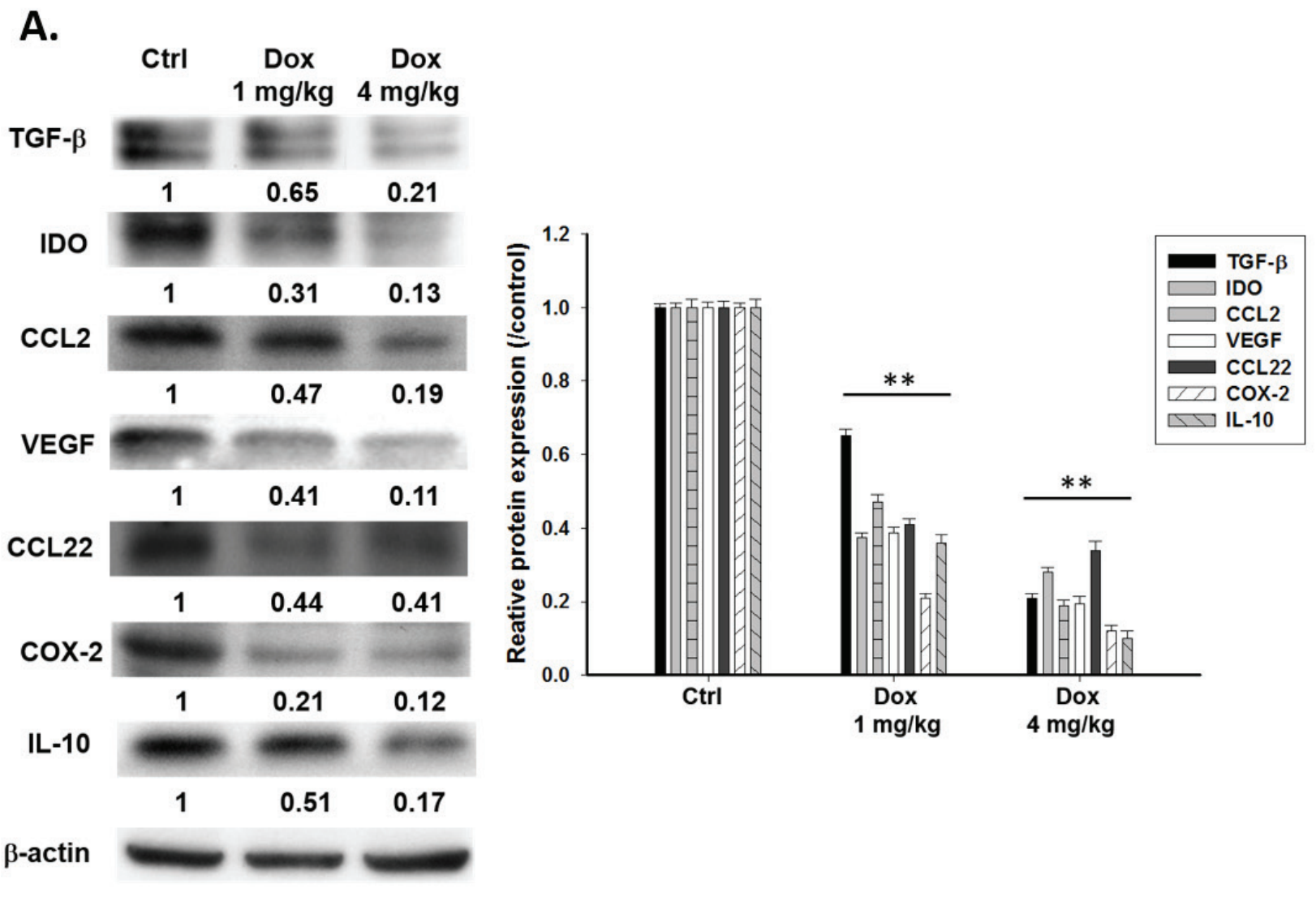

B.
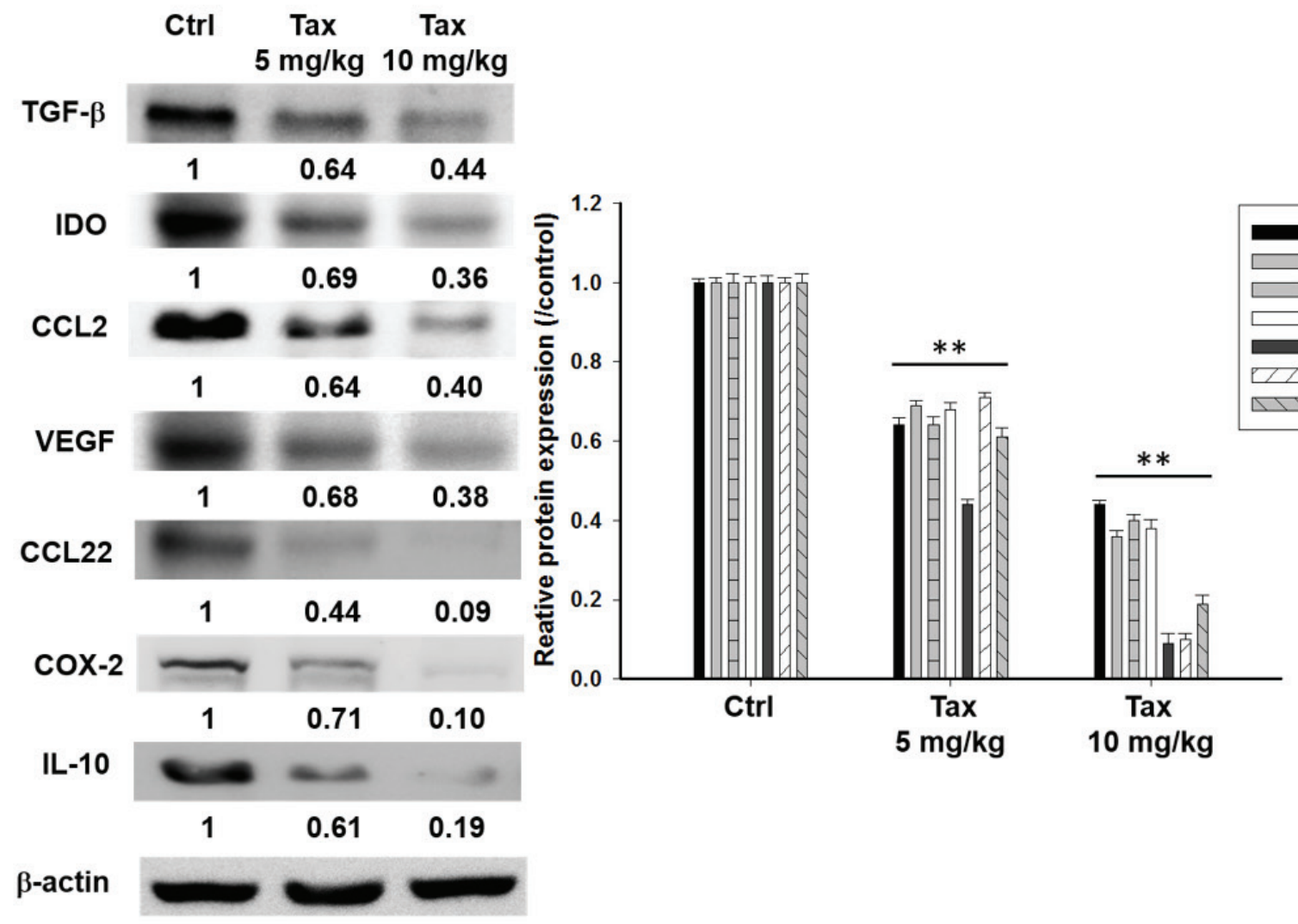


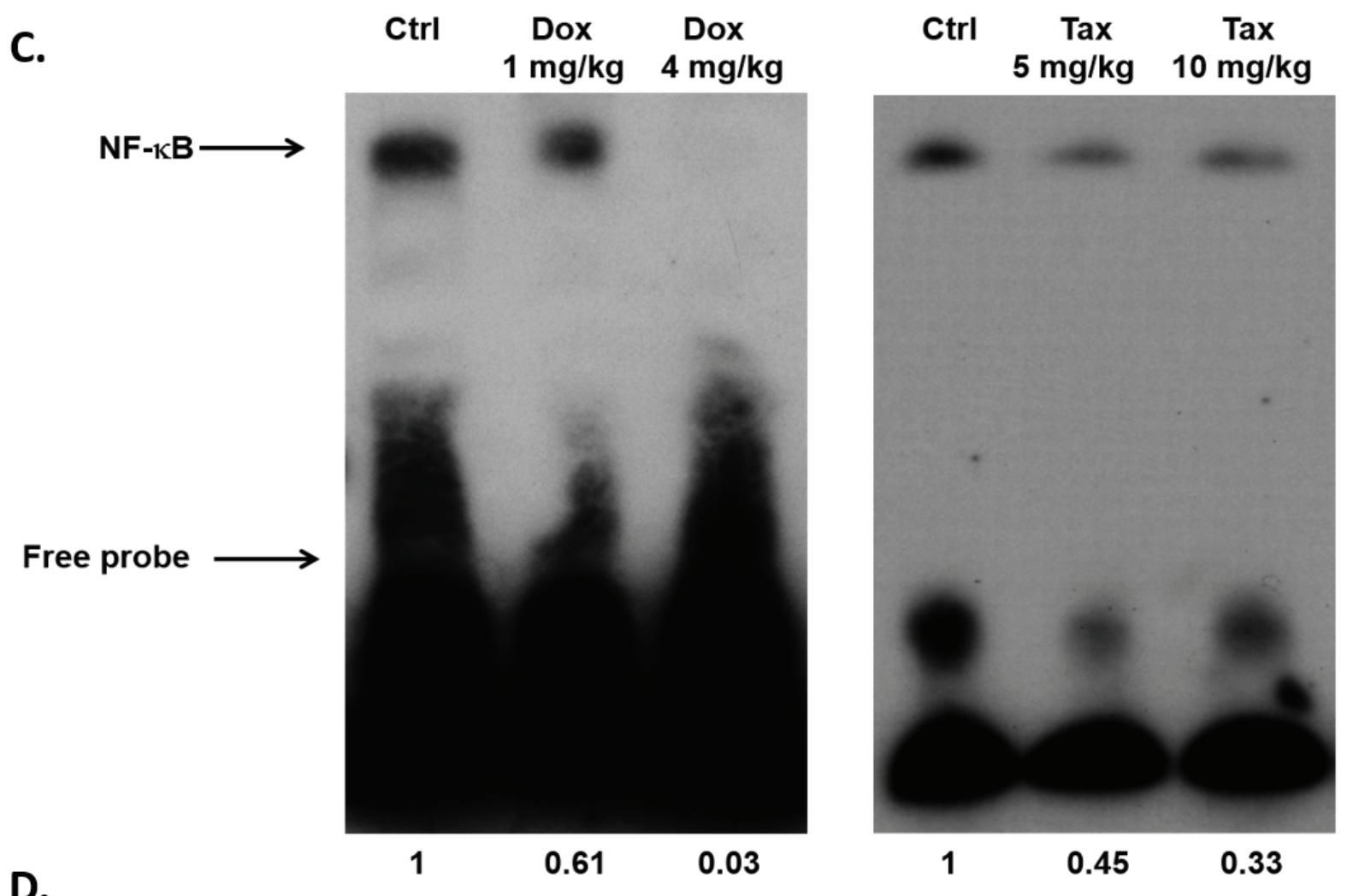

D.
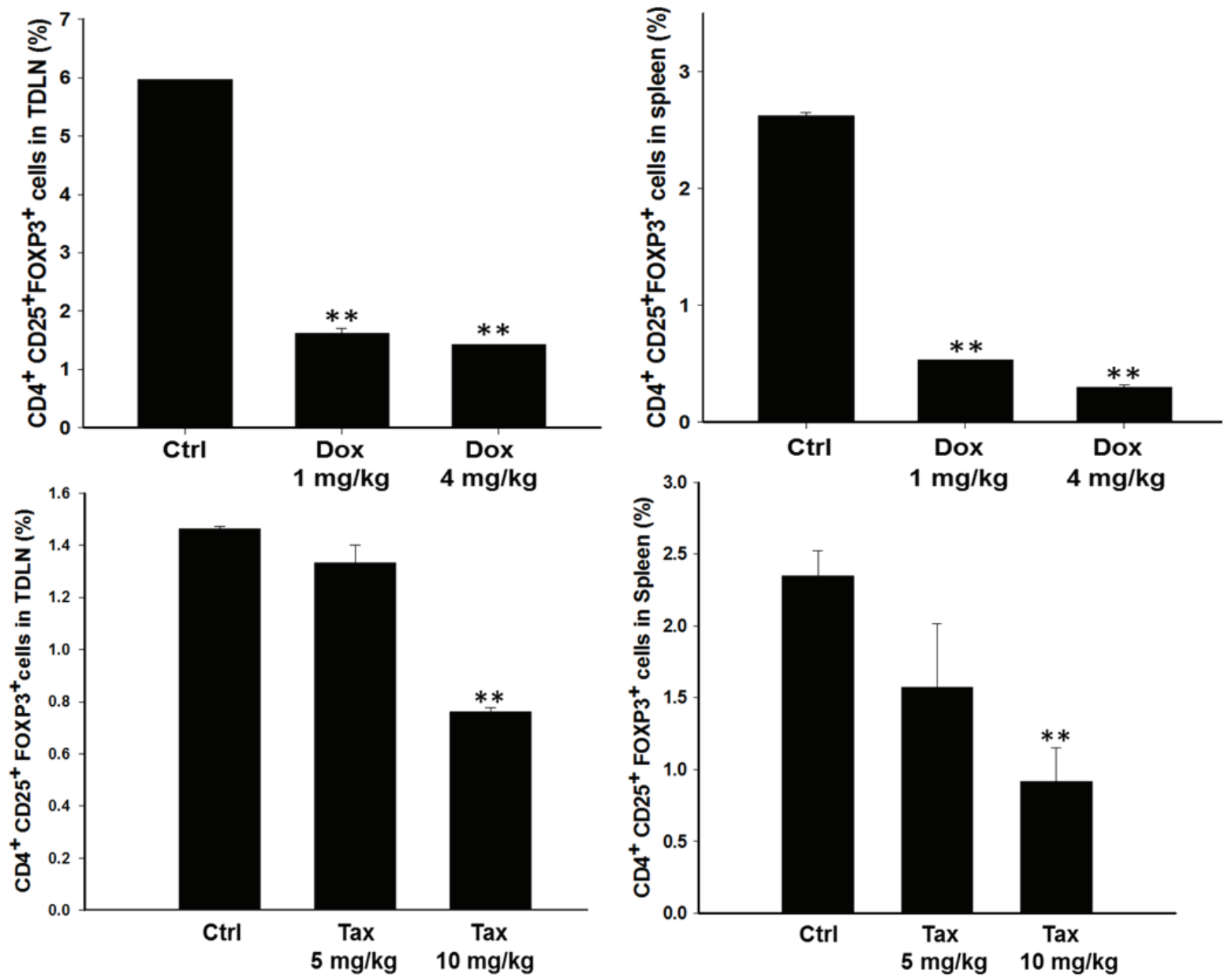
E.
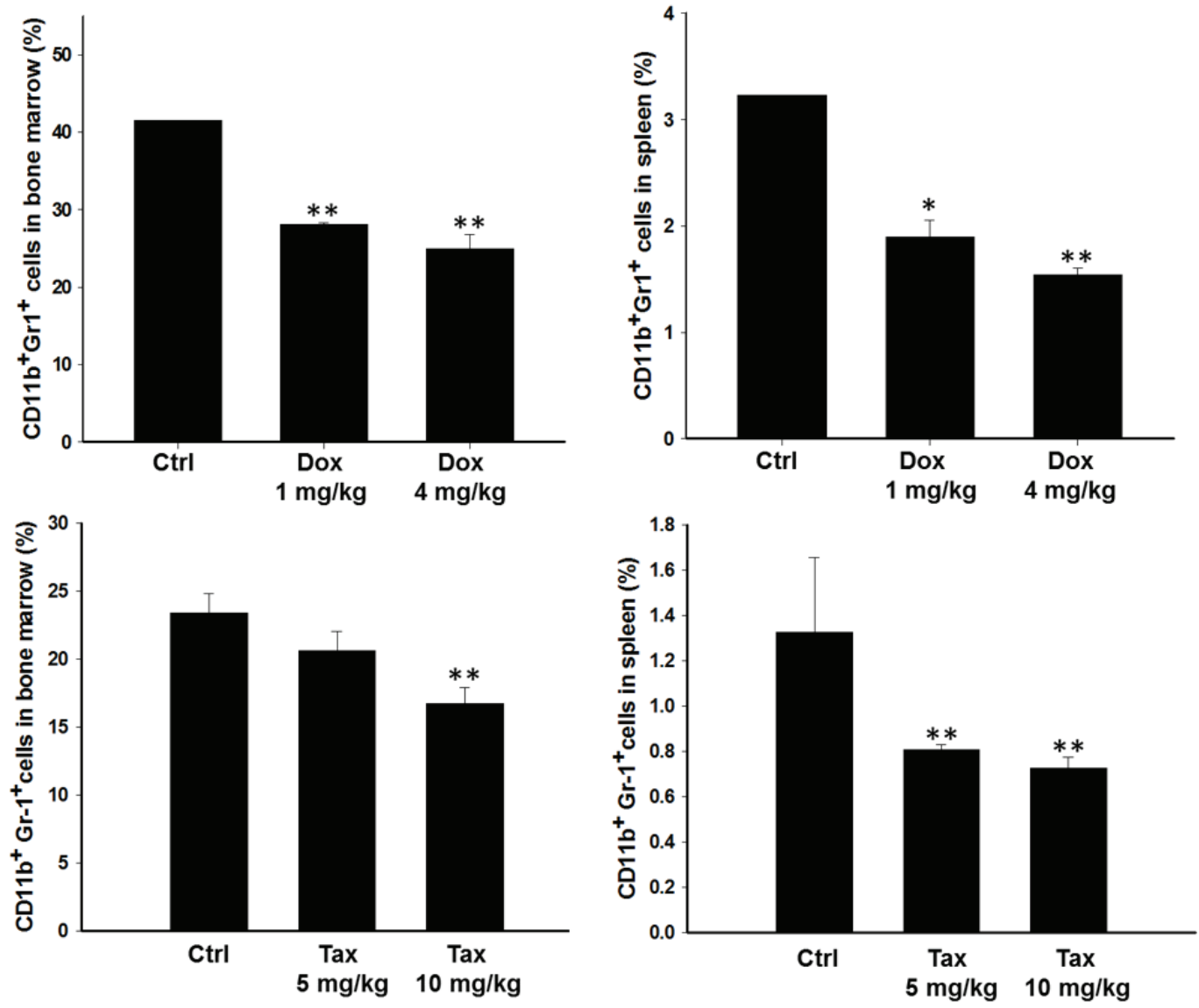

F.
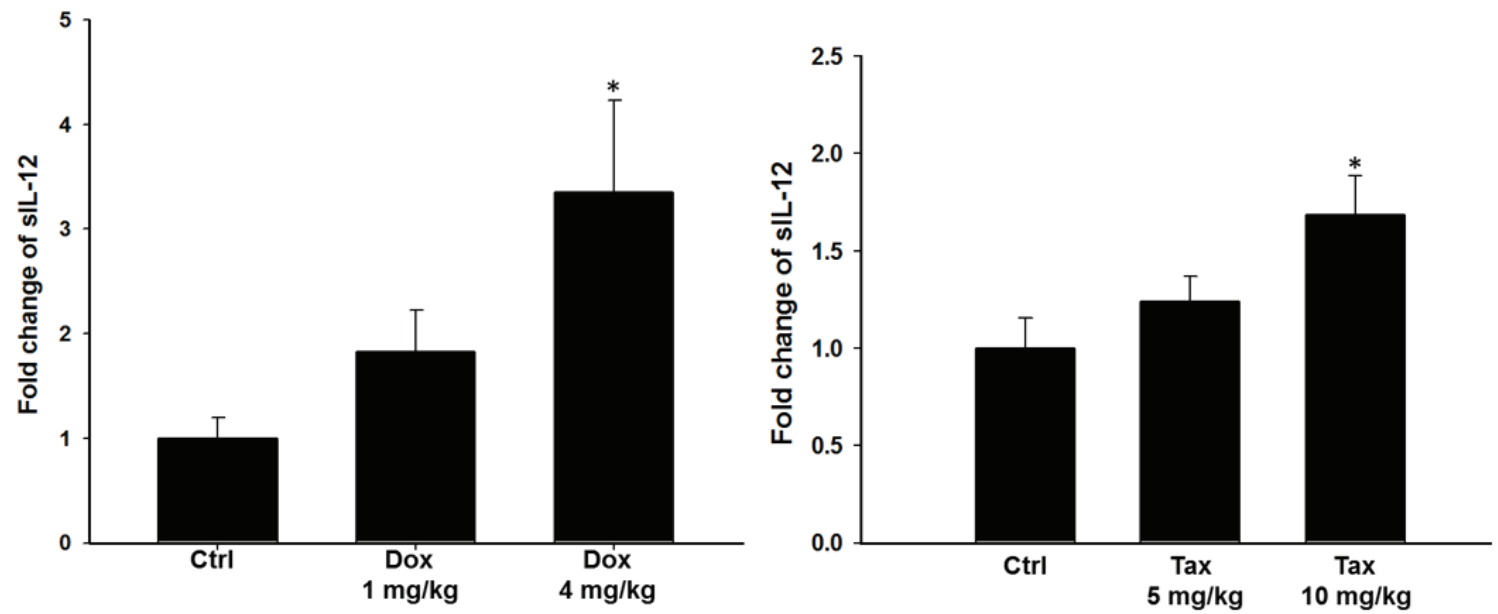

Figure 3: Immunosuppressive factors and cells were suppressed via inhibition of NF-кB three days post single low dose treatment of Dox ( 1 and $4 \mathrm{mg} / \mathrm{kg}$ ) and Tax $(5$ and $10 \mathrm{mg} / \mathrm{kg})$, respectively. The E.G7 tumor-bearing mice were established on day -7 and treated with or without single low dose of Dox or Tax on day -1 (tumor volume about $100 \mathrm{~mm}^{3}$ ) followed by ACT on day 0 . All mice were sacrificed on day 3. A.-B. Proteins extracted from tumors of Dox- or Tax-treated mice were analyzed with Western blotting. TGF- $\beta$, IDO, CCL2, VEGF, CCL22, COX-2 and IL-10 were significantly decreased in a dose-dependent manner. C. Nuclear proteins extracted from tumors of mice of each group were analyzed with EMSA. NF-kB/DNA binding activity was decreased by single low dose treatment of Dox and Tax, respectively, in a dose-dependent manner. D. Percentages of Tregs in TDLN and spleen were significantly decreased in mice treated with single low dose of Dox or Tax. E. Percentages of MDSCs in bone marrow and spleen were significantly decreased in mice treated with single low dose of Dox or Tax. F. IL-12 levels in the serum assayed by ELISA were increased in a dosedependent manner in mice treated with single low dose of Dox or Tax. ( $* x<0.05, * * p<0.01$ compared with that of the control). 


\section{DISCUSSION}

Large scale ex vivo expansion of tumor-specific T cells and the immunosuppressive tumor microenvironment have been the hindrance for clinical application of ACT $[3,4]$. The numbers, survival and activities of transferred CD8+ T-cells are factors affecting the tumor cell killing in situ during ACT [32]. To reverse the immunosuppressive tumor microenvironment may be one of the most challenging issues in cancer immunotherapy [33]. Some "off-target" effects of chemotherapeutic drugs on innate and adaptive immunity rather than cytotoxicity have been found $[25,34]$. Better tumor responses were also found in the groups received both chemotherapy and ACT $[27,35,36]$. However, myelosuppression induced by chemotherapy limits the clinical use of both Dox and Tax [37]. Here we found that single low dose pretreatment of Dox or Tax could improve the immunosuppressive tumor microenvironment through increasing the number, activity and functions of tumor-infiltrating transferred CD8+ T-cells in an E.G7/OT-1 mouse model. Hence, this strategy might be a feasible approach to improve the therapeutic efficacy of ACT. The doses of Dox and Tax used in this study are defined as "low-dose" compared with the clinical dosages based on the formula proposed by Reagan-Shaw et al. [38]. According to the formula, 1-4 mg/ $\mathrm{kg}$ Dox and $5-10 \mathrm{mg} / \mathrm{kg}$ Tax in this study were equivalent to $3-12 \mathrm{mg} /$ $\mathrm{m}^{2}$ Dox and $15-30 \mathrm{mg} / \mathrm{m}^{2}$ Tax in clinic.

The expressions of immunosuppressive factors in E.G7 cells including TGF- $\beta$, CCL2, VEGF, CCL22, COX-2 and IL-10 were decreased after treatment with low-dose Dox $(0.4 \mu \mathrm{M})$ or Tax $(12.5 \mathrm{nM})$ as shown in Figure 1A. CCL2, CCL22, TGF- $\beta$ and IL-10 augment the differentiation of M2-like tumor-associated macrophages (TAMs) and recruitment of immunosuppressors including TAMs, MDSCs and Tregs [39]. These immunosuppressors secret TGF- $\beta$, IL-10 and other chemokines, result in more immunosuppressive tumor microenvironment. CCL2 has been shown to be pivotal for immunosuppression, and the CCL2/CCR2 pathway could be a potential target for cancer therapy $[16,17]$. IDO which catalyzes tryptophan into kynurenine is overexpressed by cancer cells to
A.

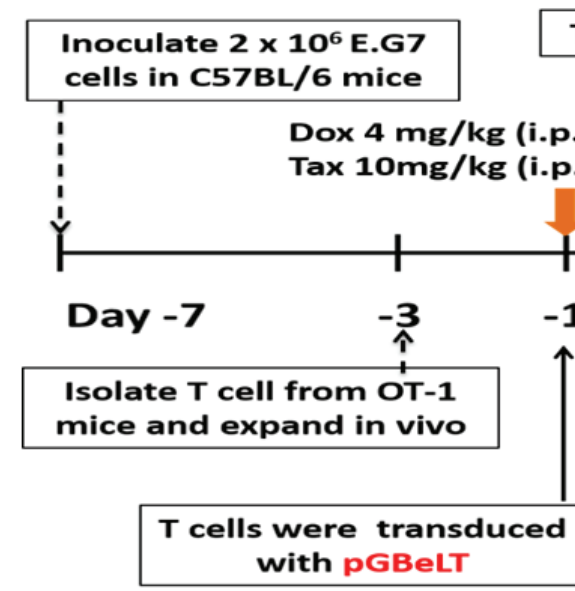

B.

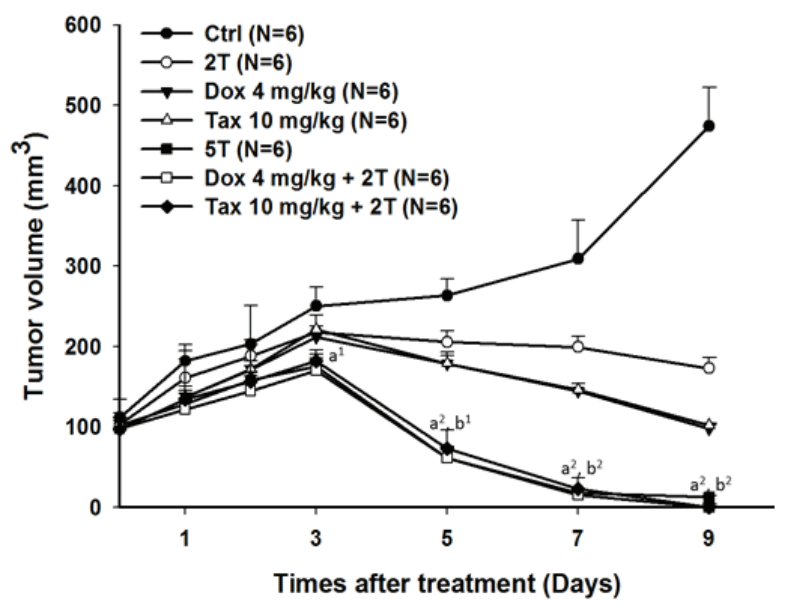

C.

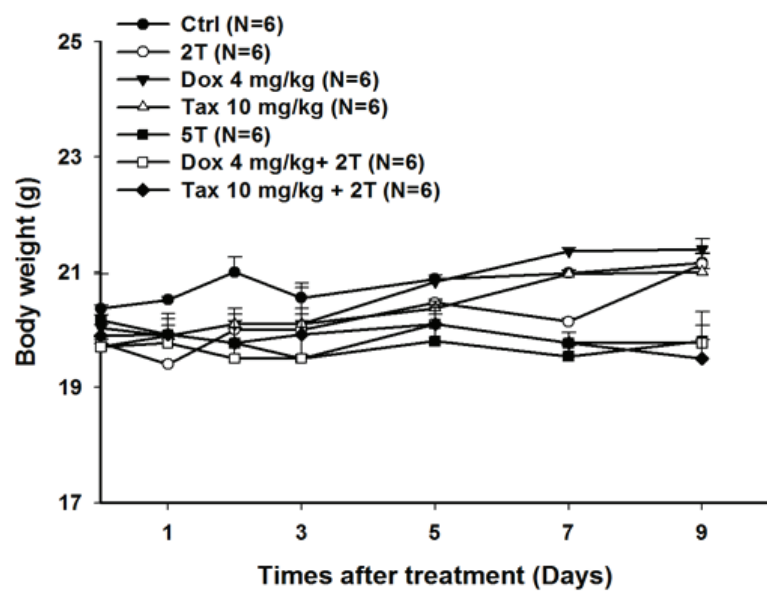

Times after treatment (Days)
Group

1. Control

2. $2 \mathrm{~T}\left(2 \times 10^{6} \mathrm{~T}\right.$ cells)

3. Dox $4 \mathrm{mg} / \mathrm{kg}$

4. Tax $10 \mathrm{mg} / \mathrm{kg}$

5. $5 \mathrm{~T}\left(5 \times 10^{6} \mathrm{~T}\right.$ cells)

6. Dox $4 \mathrm{mg} / \mathrm{kg}+2 \mathrm{~T}$

7. Tax $10 \mathrm{mg} / \mathrm{kg}+2 \mathrm{~T}$

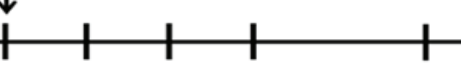

5

7

BLI

Measure the percentage

of MDSC and Treg

Ex vivo Western

EX vivo EMSA 

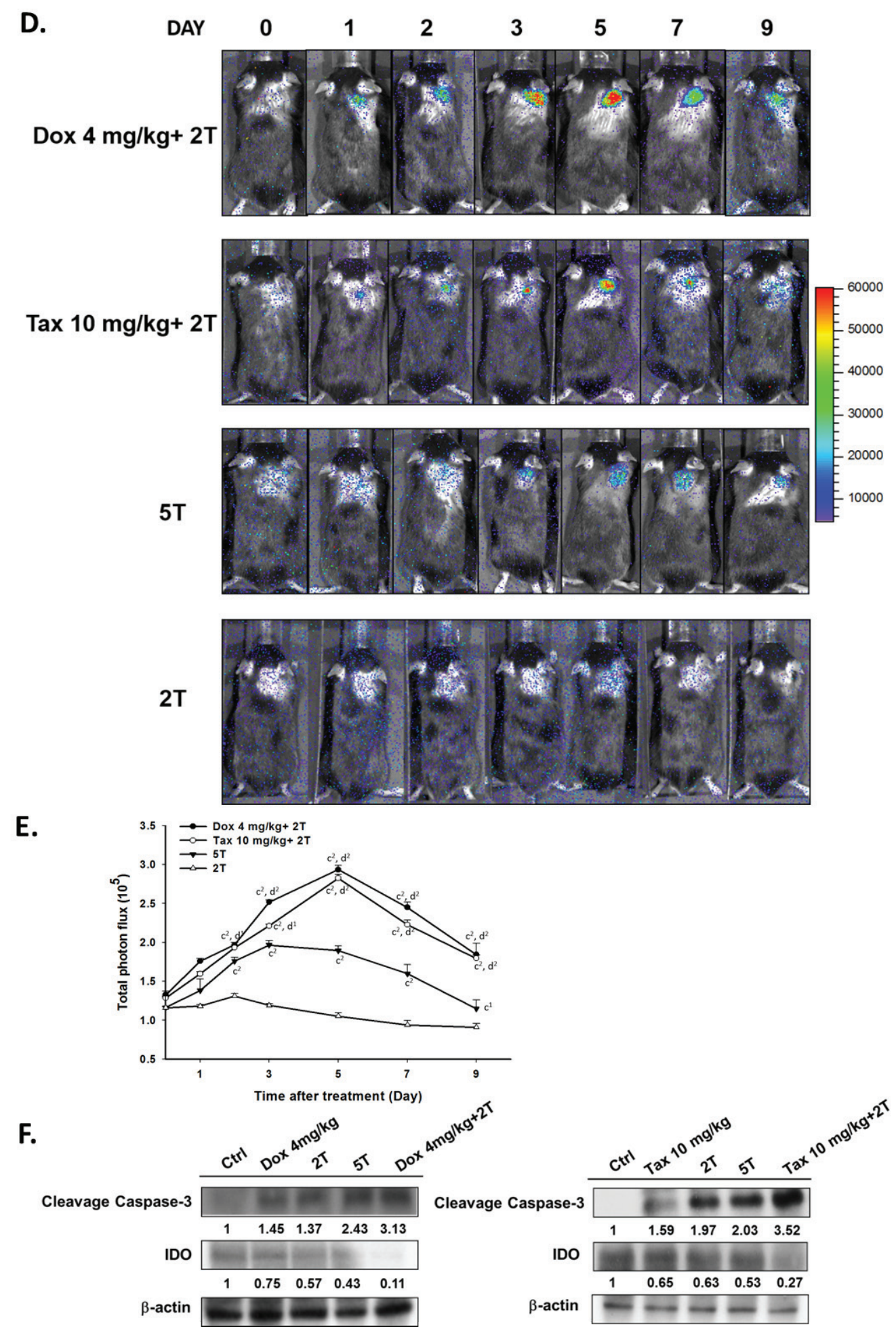

Figure 4: Therapeutic efficacy was enhanced by single low-dose Dox or Tax combined with ACT. A. the experimental design in vivo. Mice were randomly separated into seven groups as shown in figure. The ACT was performed on day 0, and single low-dose Dox or Tax was given one day before ACT (i.e. D-1). CD8+ T-cells activations were monitored by BLI; furthermore, immunosuppressive cells were also analyzed by flow cytometry. B. tumor volumes were measured by digital caliper daily. Tumors in the two combinational groups and 5T group started to shrink markedly from day 3 post ACT. C. body weight was tracked to assess the general toxicities of treatments. (a vs. Ctrl, b vs. $2 \mathrm{~T},{ }^{1} p<0.05$ and $\left.{ }^{2} p<0.01\right)$ D. $p G B e L T$-transduced $\mathrm{CD} 8+\mathrm{T}$-cells receiving mice were imaged with IVIS50 imaging system to monitor the activations of transferred CD8+ T-cells. E. the quantification of bioluminescent signals emitted from transferred CD8+ T-cells. (c vs. $2 \mathrm{~T}$, d vs. 5 T, ${ }^{1} p<0.05$ and ${ }^{2} p<0.01$ ) F. the expressions of cleavage caspase- 3 were increased in all treated groups, and the highest expressions were found in the two combinational groups. On the contrary, the IDO expression was decreased after treatments. $n=6$ per group. 
function as an immunosuppressive factor. The expressions of both endogenous and exogenous IDOs were suppressed by low-dose Dox or Tax (Figure 1B). TGF- $\beta$ also increases IDO expression through activating non-conical NF$\kappa \mathrm{B}$ pathway [40]. The $\mathrm{NF}-\kappa \mathrm{B} / \mathrm{DNA}$ binding activity detected by EMSA assay was significantly inhibited by low-dose Dox and Tax (Figure 1C). According to these results support that low-dose Dox or Tax may function as a NF- $\kappa \mathrm{B}$ inhibitor. NF- $\kappa \mathrm{B}$ may function as a substantial regulator in tumor microenvironment. Activated $\mathrm{NF}-\kappa \mathrm{B}$ in tumor cells results in high expressions of immunosuppressive factors such as IL-6, IL-10, TGF- $\beta$ and VEGF, and impedes the anti-tumor immunity [19, 41]. Since the functions and proliferation of transferred CD8+ T-cells could be impaired by immunosuppressive microenviroment [10], here co-culture of isolated CD8+ T-cells and QNZ (a NF-B inhibitor) pretreated E.G7 cells showed that the most activation (IFN- $\gamma$, IL-12, Tomato $^{+} \mathrm{T}$
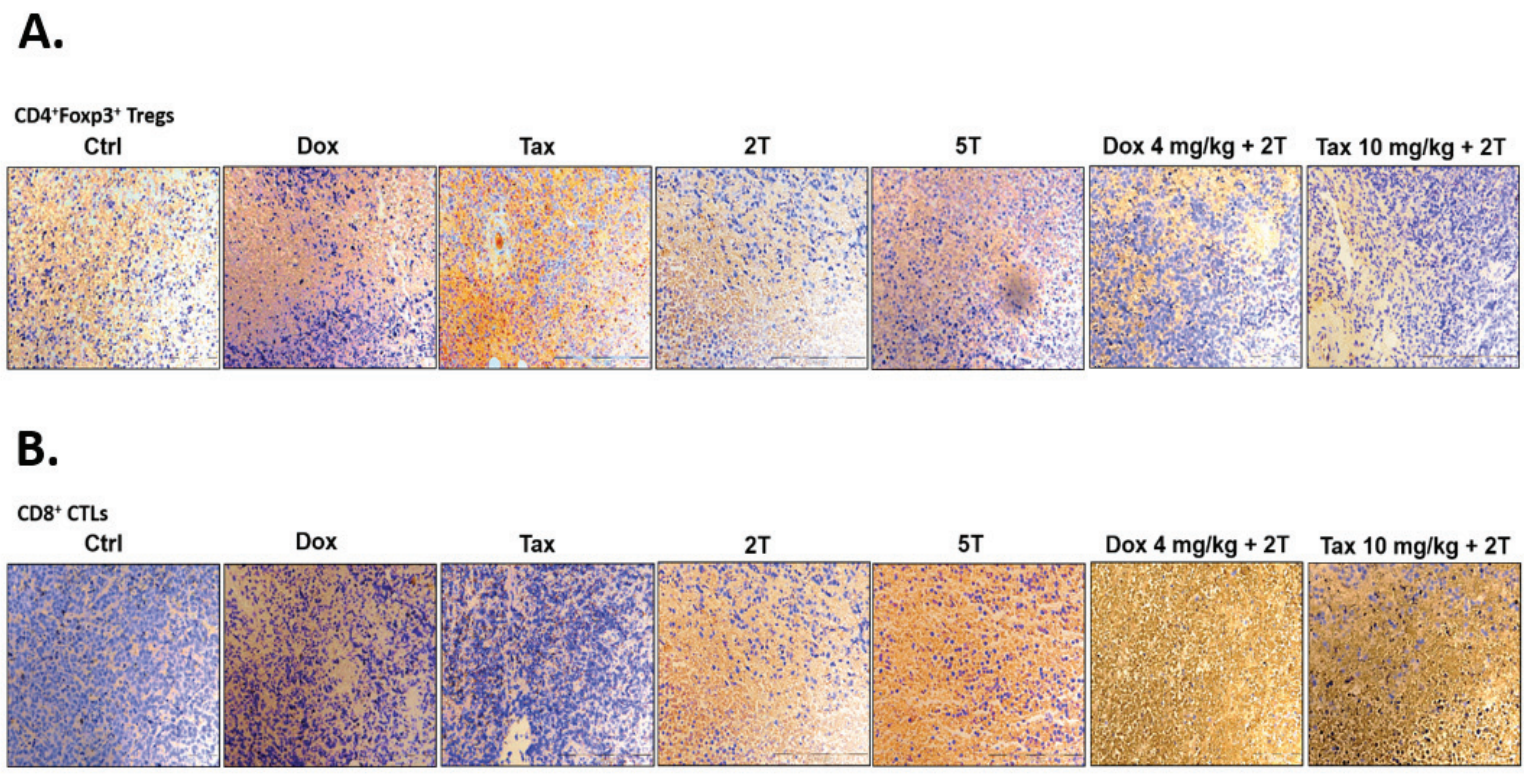

c.

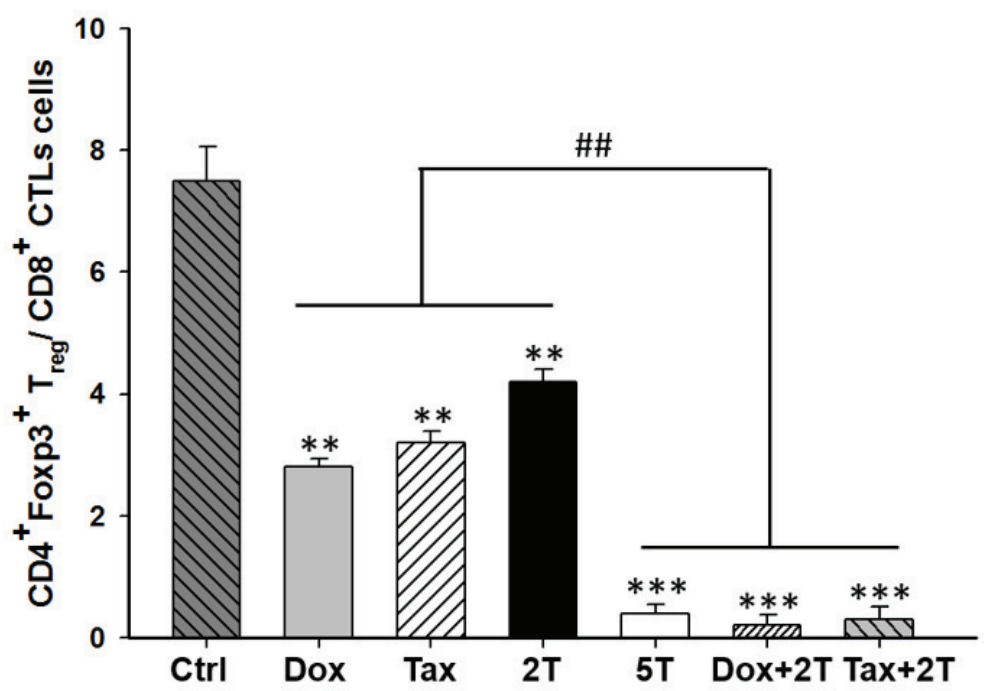

Figure 5: Single low-dose Dox or Tax increased the numbers of tumor-infiltrating CD8+ T-cells but not CD4+CD25+FOXP3+ Tregs in the combinational groups. A. tumor-infiltrating FOXP3+ cells were significantly lower in all treatment groups than that of the control group. B. CD8+ T-cells were found increased in the two combinational groups compared with the single treatment counterparts. C. ratios of FOXP3+ Tregs/CD8+ CTLs were calculated, the ratios were strikingly decreased in the combinational groups. ${ }^{* *} p<0.01,{ }^{* *} p<0.005,{ }^{*}$ compared with that of control group; $p<0.01$, \# compared with that of single treatment group). 
cells) and migration (infiltrating T cells) of CD8+ T-cells were found (Figures 2A-2D). These results conclude that inhibition of $\mathrm{NF}-\kappa \mathrm{B}$ may enhance the activation and migration of transferred CD8+ T-cells. Our animal studies further confirm these findings. NF- $\kappa \mathrm{B} / \mathrm{DNA}$ binding activity and immunosuppressive factors were decreased in tumors of mice pretreated with single lowdose Dox or Tax (Figures 3A-3C). The numbers of Tregs and MDSCs in TDLNs, spleen and bone marrow were found less accumulated (Figures 3D and 3E). Recently, Loxoribin, a TLR7 agonist, has been shown to be able to shrink the tumor through augmenting the proliferation of CD4+ T cells and lowering the frequency of Tregs, which is mediated by elevated IL-6 level secreted by DCs. [42]. IL-12 has been shown with anti-tumor effect and could enhance expressions of other cytokines involving in both innate and adaptive immunity [43]. The serum levels of IL-12 in mice were increased in a dose-dependent manner after pretreatments of low-dose Dox or Tax suggesting that the function of CD8+ T-cells might be enhanced via IL-12 regulation (Figure $3 \mathrm{~F}$ ). Together, our in vitro and in vivo results suggest that the therapeutic efficacy of ACT could be improved when pretreated with single low dose of Dox or Tax.

Recently, the outcome of ACT in breast cancer has been shown to be enhanced by low-dose Dox $(5 \mathrm{mg} / \mathrm{kg}$ i.v.) plus $\mathrm{Th}_{1}$ or $\mathrm{Th}_{17}$ cells (i.v. or intratumoral), which results in increased proliferations of CD8+ T-cells and NK cells through elimination of MDSCs [43]. Here we demonstrated that single low-dose Dox (4 mg/kg i.p.) or Tax $(10 \mathrm{mg} / \mathrm{kg}$ i.p. $)$ administered one day prior to ACT which used fewer numbers of CD8+ T-cells (i.e. Dox $+2 \times 10^{6} \mathrm{~T}$ cells or Tax $+2 \times 10^{6} \mathrm{~T}$ cells) could achieve the same tumor inhibition efficacy as that of $5 \mathrm{x}$ $10^{6} \mathrm{~T}$ cells group. Since transferred CD8+ T-cells traffic indiscriminately and ubiquitously into various tissues/ organs and may cause potential side effects [44], thus minor or neglected adverse effects related to transferred CD8+ T-cells could be avoided with this combinational strategy. The activation and survival of transferred CD8+ T-cells were improved in combinational groups assayed by $p G B e L T$ system (Figures 4D and 4E). Moreover, the numbers of tumor-infiltrating CD8+ T-cells and Tregs have been reported to closely correlate with the
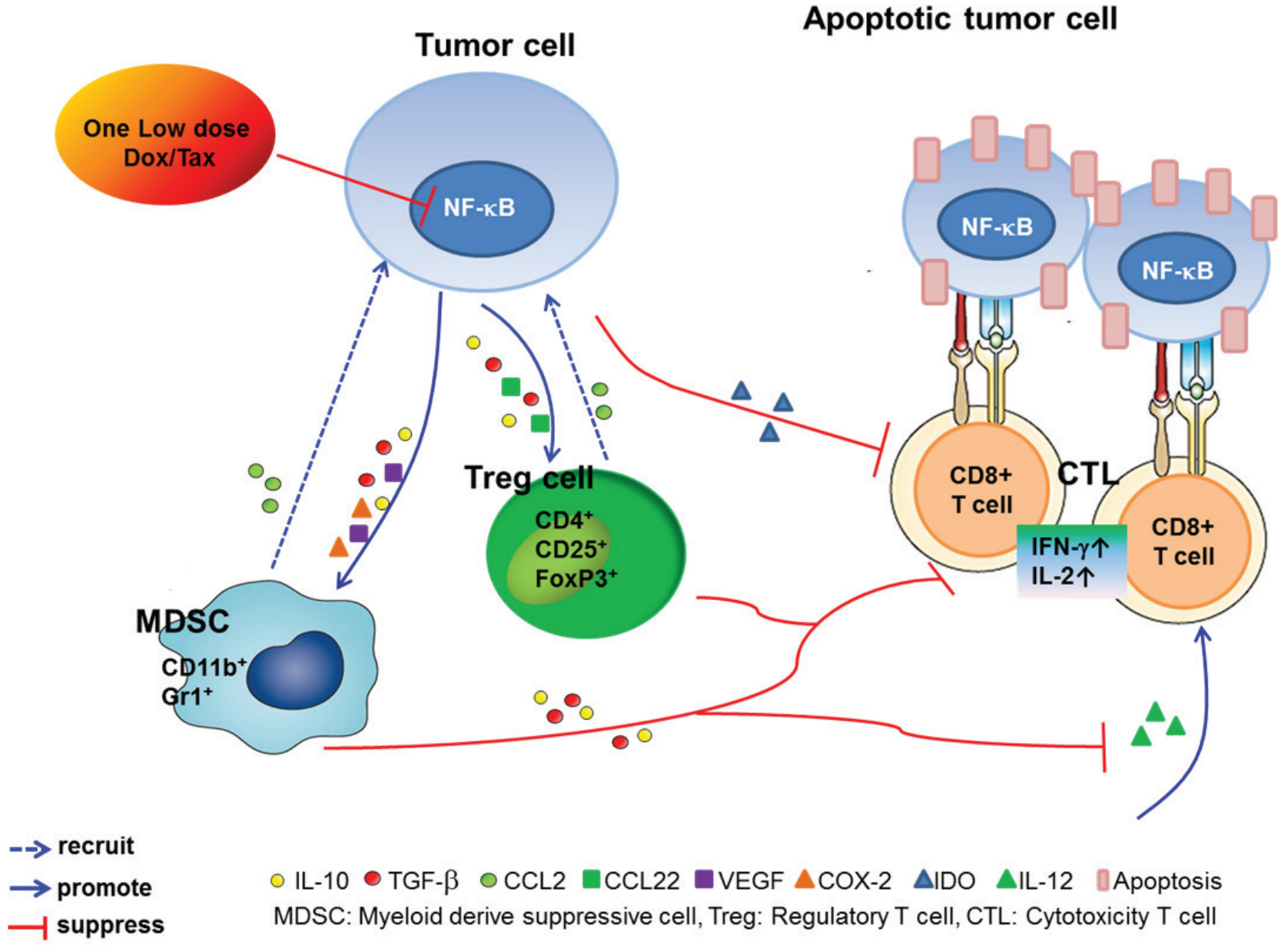

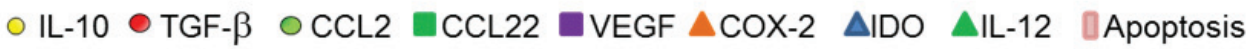
MDSC: Myeloid derive suppressive cell, Treg: Regulatory T cell, CTL: Cytotoxicity T cell

Figure 6: The proposed underlying mechanism for modulation of the immune tumor microenvironment and enhancement of the therapeutic efficacy of ACT in cancer pretreated with one low-dose Dox or Tax. 
prognosis and survival of patients $[45,46]$. Alternatively, the expansion efficiency and the cell function also could be enhanced by the culturing strategy such as using the bone marrow multipotent mesenchymal stromal cells (BM-MMSC) [47]. Here we have shown that the activity and number of tumor-infiltrating CD8+ T-cells were strikingly increased while the number of tumor-infiltrating Tregs was diminished in combination groups (Figures 5A$5 \mathrm{C})$. The expression of cleaved caspase-3 in tumors was also significantly increased in combination groups (Figure $5 \mathrm{~F}$ ), suggesting that tumor cell killing by CD8+ T-cells was through the apoptotic pathway.

In conclusion, our results suggest that tumorbearing mice pretreated with single low-dose Dox or Tax may improve the therapeutic efficacy of ACT which using two millions, instead of five millions, of CD8+ T-cells for the treatment of cancer. The therapeutics of possible underlying mechanisms are the improvement of the tumor microenvironment through the suppression of NF- $\kappa \mathrm{B}$ and subsequent cytokines such as TGF- $\beta$, IL10, VEGF, COX-2, CCL2 and CCL22, and enhancement the function of transferred CD8+ T-cells (Figure 6). This combination strategy may be potential to overcome the current limitation of ACT in clinic.

\section{MATERIALS AND METHODS}

\section{Cell culture and reagents}

OVA-expressing E.G7 mouse lymphoma cell line and Jurkat human T-cell leukemia cell line purchased from American Type Culture Collection (ATCC; Jan 2010) were maintained in cRPMI-1640 (RPMI-1640, 10\% FBS, 1\% penicillin/streptomycin, and $25 \mathrm{mM}$ HEPES) with 400 $\mu \mathrm{g} / \mathrm{mL}$ G418. Lentiviral-producing HEK-293FT cell line from Invitrogen (Jan 2010) was maintained in cDMEM [Dulbecco's modified Eagle's medium (DMEM), 10\% FBS, 1\% penicillin/streptomycin, $2 \mathrm{mM}$ L-glutamine, and $0.1 \mathrm{mM}$ MEM nonessential amino acids] with $500 \mu \mathrm{g} / \mathrm{ml}$ G418. All cell lines were authenticated by short tandem repeat profiling prior to their usage and passed for less than 6 months in our experiments. Cell culture tested Myacoplasm free routinely with MycoAlert Mycoplasma Detection Assay (Lonza). Lentiviral production and titration assay were performed as previously described [26]. 6-Amino-4-(4-phenoxyphenylethylamino) quinazoline (QNZ, Millipore), a NF- $\mathrm{B}$ inhibitor, was dissolved in $0.1 \%$ dimethyl sulfoxide (DMSO, Sigma) and prepared $1 \mathrm{mM}$ as stock solution. Doxorubicin (Pfizer) was dissolved in $0.1 \%$ DMSO and prepared $1 \mathrm{mM}$ as stock solution for in vitro studies. For in vivo studies, Dox was dissolved in $0.1 \%$ DMSO and prepared $10 \mathrm{mg} / \mathrm{ml}$ as stock solution. Paclitaxel (6 mg/ml/vial) was purchased from Yung Shin Pharm. Ind. Co., Ltd, Taiwan, and was prepared $10 \mu \mathrm{M}$ as stock solution for in vitro study. All stock solutions were stored at $-20^{\circ} \mathrm{C}$. The doses used in vivo were 1 and $4 \mathrm{mg} / \mathrm{kg}$ for Dox and 5 and $10 \mathrm{mg} / \mathrm{kg}$ for Tax $[37,48]$, respectively.

\section{Animals}

Eight-week-old male C57BL/6 mice purchased from the National Laboratory Animal Center, Taiwan and OT-1 transgenic mice obtained from the Jackson Laboratory were housed in the laboratory animal center of National Yang-Ming University, and maintained as previously described [27]. All animal protocols were approved by the Animal Care and Use Committee at National YangMing University (permits number: 1000522). All animal experiment was followed by the UKCCCR guidelines for the welfare of animals in experimental neoplasia [49].

\section{Isolation and transduction of mouse CD8+ T-cells}

Isolation and transduction were performed as previously described [26, 27]. In brief, CD8+ T-cells isolated from spleens of OT-1 mice were enriched by mouse T cell enrichment kit (Stemcell Technologies), then cultured in cRPMI-1640 medium containing $2.5 \mu \mathrm{g} / \mathrm{ml}$ Concanavalin A (Calbiochem), $50 \mu \mathrm{M} \beta$-mercaptoethanol (Bio-Rad), $10 \mathrm{ng} / \mathrm{ml} \mathrm{IL-7} \mathrm{(R \& D} \mathrm{Systems)} \mathrm{for} 36$ hours. CD8+ T-cells were transduced with $p G B e L T$ lentiviruses $(\mathrm{MOI}=5)$ for 4 hours, and cultured in cRPMI-1640 medium containing $50 \mu \mathrm{M} \beta$-ME, $10 \mathrm{ng} / \mathrm{mL} \mathrm{IL-15}$ and $10 \mathrm{U} / \mathrm{mL}$ IL-2 (R\&D Systems), and $50 \mathrm{mM} \alpha$-methyl mannoside (Calbiochem) for another 24 hours.

\section{Cytotoxicity of Dox, Tax and NF-kB inhibitor on E.G7 cells}

$1 \times 10^{5}$ E.G7 cells/well were cultured in 96-well plate and treated with various concentrations of Dox, Tax and QNZ, respectively, for 24 hours. Cytotoxicity was determined by AlamarBlue assay. Briefly, 10\% AlamarBlue reagent containing cRPMI-1640 (product code: BUF012B, AbD Serotec) was added to cells and incubated at $37^{\circ} \mathrm{C}$ for 4 hours. The fluorescent signals were detected at $570 \mathrm{~nm}$ and $600 \mathrm{~nm}$, respectively, using ELISA reader (TECAN Sunrise). Cell viability was calculated using the equation provided by the manufacture.

\section{Transwell assay}

$1 \times 10^{6}$ E.G7 cells/well pretreated with or without $0.4 \mu \mathrm{M}$ Dox, $12.5 \mathrm{nM}$ Tax and $5 \mathrm{nM}$ QNZ, respectively, were resuspended in $500 \mu \mathrm{l}$ cRPMI-1640 and seeded into 24-well plates. CD8+ T-cells were resuspended in cRPMI-1640 at a density of $2 \times 10^{6}$ cells $/ \mathrm{ml}$, and $100 \mu \mathrm{l}$ 
of CD8+ T-cells suspension was added into the upper compartment of $5 \mu \mathrm{m}$ transwell inserts (Corning Costar). After 4 hours incubation, the membranes were fixed, stained with hematoxylin and air-dried. The number of migratory $\mathrm{CD} 8+\mathrm{T}$ cells was photographed and counted under Leica DM IRB microscope (Deerfield) with 100x magnification, and five fields per slide were scored.

\section{Flow cytometric analysis}

After 4 hours co-culture, the activations of CD8+ T-cells were determined by the expressions of tomato fluorescent protein, intracellular IFN- $\gamma$ and IL-2 (Biolegend) using flow cytometry. For in vivo study, the tumor draining lymph nodes (TDLNs) and bone marrow from the vehicle, Dox- and Tax-treated mice were harvested and analyzed on day 3 post Dox and Tax administration to trace the percentages of Tregs and MDSCs ( $n=6$ per group). The single cell suspensions isolated from the spleen, TDLNs and bone marrow were stained with anti-FOXP3-Alexa Fluor 488/CD4APC/CD25-PE antibodies using a Mouse Treg Flow Kit (Biolegend) according to manufacturer's protocol, and CD11b-FITC and Gr-1-PE antibodies (eBioscience) for detecting Tregs and MDSCs, respectively. The percentages of these cell types were acquired using FACSCalibur flow cytometry (BD Bioscience), and data were analyzed by FlowJo software (Tree Star).

\section{Western blotting}

To assess the expressions of immunosuppressive factors, proteins were extracted from E.G7 cells or removed tumors using lysis buffer and T-PER kit (Thermo Scientific), respectively. For in vitro studies, $1 \times 10^{6}$ E.G7 cells were seeded into each $10-\mathrm{cm}$ diameter culture dish and treated with Dox, Tax and QNZ, respectively, for 24 hours prior to protein extraction. $500 \mathrm{U} / \mathrm{ml} \mathrm{IFN}-\gamma$ (BD Biosciences) was added into the medium to stimulate E.G7 cells to evaluate whether Dox, Tax and QNZ could inhibit the expression of exogenous IDO. Protein lysates were separated by $10-15 \%$ SDS-PAGE, transferred to polyvinylidene difluoride membrane (Pall), blocked with 5\% nonfat milk dissolved in TBST (Tris-buffered saline containing $0.1 \%$ Tween-20) at room temperature for 1 hour. The membranes were incubated with primary antibodies against anti-IDO, anti-COX-2 (Millipore), TGF- $\beta$, CCL2, (Cell Signaling), anti-MDC (CCL22), antiVEGF, anti-IL-10 and $\beta$-actin (Abcam) at $4^{\circ} \mathrm{C}$ overnight. After washed with TBST, the membranes were incubated with horseradish peroxidase-conjugated secondary antibodies (Jackson ImmunoResearch Laboratories Inc.) for 1 hour at room temperature. Finally, the proteins of interest were visualized by the Image Quant LAS-4000 (Fujifilm) with the ECL chemiluminescent detection system (Merck Millipore). ImageJ (National Institutes of Health) was used for the quantitative analysis. The experiments were repeated more than three times.

\section{Drug treatments and adoptive $T$ cell transfer in E.G7-bearing mouse model}

$2 \times 10^{6}$ E.G7 cells were inoculated subcutaneously into each C57BL/6 male mouse. When the average tumor size reached about $100 \mathrm{~mm}^{3}$, mice were randomly divided into seven groups ( $\mathrm{n}=6$ per group): vehicle (control), $4 \mathrm{mg} / \mathrm{kg}$ Dox (Dox), $10 \mathrm{mg} / \mathrm{kg}$ Tax (Tax), 2x10 CD8+ T-cells (2T), $5 \times 10^{6} \mathrm{CD} 8+\mathrm{T}$-cells (5T), $4 \mathrm{mg} / \mathrm{kg}$ Dox plus $2 \times 10^{6} \mathrm{CD} 8+\mathrm{T}$-cells $(\mathrm{Dox}+2 \mathrm{~T})$ and $10 \mathrm{mg} / \mathrm{kg}$ Tax plus $2 \times 10^{6} \mathrm{CD} 8+\mathrm{T}$-cells $(\mathrm{Tax}+2 \mathrm{~T})$. Single dose of $4 \mathrm{mg} / \mathrm{kg}$ Dox or $10 \mathrm{mg} / \mathrm{kg}$ Tax was administered via i.p. injection, and transferred OT-1 CD8+ T-cells were given by i.v. injection. For the combination therapy, Dox or Tax was given 24 hours before CD8+ T-cells transfer (see Fig. 4A for details). Tumor volumes were measured with a caliper and calculated by the formula: length $\mathrm{x}$ width ${ }^{2} \mathrm{x} 0.523$. The experiments were repeated three times.

\section{Electrophoretic mobility shift assay (EMSA)}

Nuclear proteins were isolated from cells or tumor tissues using Nuclear Extraction Kit (Chemicon International). The NF- $\mathrm{kB} / \mathrm{DNA}$ binding activity was evaluated using the LightShift Chemiluminescent EMSA kit (Pierce). The isolation and analysis were performed using protocols provided by the manufacturer. The following DNA sequences were synthesized for EMSA analysis: AGTTGAGGGGACTTTCCCAGGC (sense) and GCCTGGGAAAGTCCCCTCAACT (antisense). Briefly, nuclear extracts were incubated with the biotin-labeled DNA probe for $20 \mathrm{~min}$ at room temperature. The DNAprotein complex was separated from free oligonucleotides on a $5 \%$ polyacrylamide gel, then transferred to a nylon membrane and cross-linked by UV light. The membranes were further incubated with streptavidin-horseradish peroxidase, and detected by enhanced ECL. The imageJ software was used for the quantitative analysis. The experiments were repeated three times.

\section{Enzyme-linked immunosorbent assay (ELISA)}

Circulating bloods were drawn from the facial vein on day 3 after one low-dose Dox or Tax treatment, and serum samples were prepared by centrifugation at 2000 $\mathrm{rpm}$ for $10 \mathrm{~min}$ post coagulation. The level of serum IL12 was determined by IL-12 ELISA kit (R\&D Systems). 


\section{Bioluminescent imaging (BLI) in vivo}

Mice ( $n=6$ per group) receiving $p G B e L T$ transduced CD8+T cells were i.p. injected with $150 \mathrm{mg} /$ $\mathrm{kg}$ D-luciferin for $15 \mathrm{~min}$, then anesthetized with 1-3\% isoflurane for imaging. The emitted photons were detected by the IVIS50 Imaging System (Xenogen) for $5 \mathrm{~min}$. The Living Image software (Version 2.20, Xenogen) was used to quantify the signals emitted from the regions of interest (ROIs).

\section{Immunohistochemistry}

Tumors removed from mice were frozen in TissueTek OCT compound (Sakura Finetek) and sectioned with $10 \mu \mathrm{m}$ thickness, and mounted on glass slides. Sections were incubated with $3 \% \mathrm{H}_{2} \mathrm{O}_{2}$ for $10 \mathrm{~min}$ to quench the endogenous peroxidase activity, then rinsed with PBS. Slides were incubated with primary antibodies against CD8 and FOXP3 at $4^{\circ} \mathrm{C}$ overnight, developed with diaminobenzidine tetrahydrochloride (DAB), and finally counterstained with hematoxylin. All the staining procedures were followed the protocols provided by the manufacturer of IHC Select HRP/DAB kit (Millipore). CD8+ cells were defined as CTLs, and FOXP3+ cells were defined as Tregs. Slides were imaged with Olympus BX 61 microscope equipped with color CCD under $100 \mathrm{x}$ magnification. Five slides were imaged and analyzed per group.

\section{Statistical analysis}

All data were shown as the mean \pm standard error. Student's $t$-test was used for the comparison between two groups. One-way ANOVA followed by Tukey's post hoc test was used when comparing more than two groups. Difference between the means were considered significant if $p<0.05$ or less.

\section{FUNDING}

This study was supported by grants NSC 100-2314B-010 -016, NSC 100-2321-B-010-013, NSC 101-2321B-010-006 and NSC 102-2321-B-010-005 from Ministry of Science and Technology, Taipei Taiwan. Biophotonics \& Molecular Imaging Research Center, National YangMing University, Taipei, Taiwan. The authors thank the Taiwan Mouse Clinic (MOST 103-2325-B-001-015) which is funded by the National Research Program for Biopharmaceuticals (NRPB) from Ministry of Science and Technology (MOST) of Taiwan for technical support in bioluminescent imaging.

\section{CONFLICTS OF INTEREST}

No potential conflicts of interest were disclosed.

\section{REFERENCES}

1. Gattinoni L, Powell DJ Jr., Rosenberg SA, Restifo NP. Adoptive immunotherapy for cancer: building on success. Nat Rev Immunol 2006; 6: 383-393.

2. Rosenberg SA, Packard BS, Aebersold PM, Solomon D, Topalian SL, Toy ST, Simon P, Lotze MT, Yang JC, Seipp CA, Colleen S, Charles C, Steven B, et al. Use of tumor-infiltrating lymphocytes and interleukin-2 in the immunotherapy of patients with metastatic melanoma. A preliminary report. N Engl J Med 1988; 319: 1676-1680.

3. June CH. Adoptive $\mathrm{T}$ cell therapy for cancer in the clinic. J Clin Invest 2007; 117: 1466-1476.

4. Brenner MK, Heslop HE. Adoptive T cell therapy of cancer. Curr Opin Immunol 2010; 22: 251-257.

5. Kim R, Emi M, Tanabe K. Cancer immunoediting from immune surveillance to immune escape. Immunology 2007; 121: 1-14.

6. di Bari MG, Lutsiak ME, Takai S, Mostböck S, Farsaci B, Semnani RT. TGF-beta modulates the functionality of tumor-infiltrating CD8+ T-cells through effects on TCR signaling and Spred1 expression. Cancer Immunol Immunother 2009; 58: 1809-1818.

7. Li MO, Wan YY, Sanjabi S, Robertson AK, Flavell RA. Transforming growth factor-beta regulation of immune responses. Ann Rev Immunol 2006; 24: 99-146.

8. Wan YY, Flavell RA. 'Yin-Yang' functions of transforming growth factor-beta and $\mathrm{T}$ regulatory cells in immune regulation. Immunol Rev 2007; 220: 199-213.

9. Sato T, Terai M, Tamura Y, Alexeev V, Mastrangelo MJ, Selvan SR. Interleukin 10 in the tumor microenvironment: a target for anticancer immunotherapy. Immunol Res 2011; 51: 170-182.

10. Leen AM, Rooney CM, Foster AE. Improving $\mathrm{T}$ cell therapy for cancer. Annu Rev Immunol 2007; 25: 243-265.

11. Weed DT, Vella JL, Reis I, De La Fuente AC, Gomez C, Sargi Z, Nazarian R, Califano J, Borrello I, Serafini P. Tadalafil reduces myeloid derived suppressor cells and regulatory $\mathrm{T}$ cells and promotes tumor immunity in patients with head and neck squamous cell carcinoma. Clin Cancer Res 2015; 21: 39-48.

12. Melero I, Rouzaut A, Motz GT, Coukos G. T-cell and NKcell infiltration into solid tumors: a key limiting factor for efficacious cancer immunotherapy. Cancer Discov 2014; 4: 522-526.

13. Lindau D, Gielen P, Kroesen M, Wesseling P, Adema GJ. The immunosuppressive tumour network: myeloid-derived suppressor cells, regulatory $\mathrm{T}$ cells and natural killer $\mathrm{T}$ cells. Immunology 2013; 138: 105-115.

14. Uyttenhove C, Pilotte L, Theate I, Stroobant V, Colau D, 
Parmentier N, Boon T, Van den Eynde BJ. Evidence for a tumoral immune resistance mechanism based on tryptophan degradation by indoleamine 2,3-dioxygenase. Nature Med 2003; 9: 1269-1274.

15. Sharma MD, Hou DY, Liu Y, Koni PA, Metz R, Chandler P, Mellor AL, He Y, Munn DH. Indoleamine 2,3-dioxygenase controls conversion of Foxp3 + Tregs to TH17-like cells in tumor-draining lymph nodes. Blood 2009; 113: 6102-6111.

16. Fridlender ZG, Buchlis G, Kapoor V, Cheng G, Sun J, Singhal S, Crisanti MC, Wang LC, Heitjan D, Snyder LA, Albelda SM. CCL2 blockade augments cancer immunotherapy. Cancer Res 2010; 70: 109-118.

17. Kudo-Saito C, Shirako H, Ohike M, Tsukamoto N, Kawakami Y. CCL2 is critical for immunosuppression to promote cancer metastasis. Clin Exp Metastas 2013; 30: 393-405.

18. Gallo O, Franchi A, Magnelli L, Sardi I, Vannacci A, Boddi V, Chiarugi V, Masini E. Cyclooxygenase-2 pathway correlates with VEGF expression in head and neck cancer. Implications for tumor angiogenesis and metastasis. Neoplasia 2001; 3: 53-61.

19. Ben-Neriah Y, Karin M. Inflammation meets cancer, with $\mathrm{NF}-\kappa \mathrm{B}$ as the matchmaker. Nat Immunol 2011; 12: 715723.

20. Escárcega RO, Fuentes-Alexandro S, García-Carrasco M, Gatica A, Zamora A. The Transcription Factor Nuclear Factor-kappa B and Cancer. Clin Oncol 2007; 19: 154-161.

21. Greten FR, Eckmann L, Greten TF, Park JM, Li ZW, Egan LJ, Kagnoff MF, Karin M. IKKbeta links inflammation and tumorigenesis in a mouse model of colitis-associated cancer. Cell 2004; 118: 285-296.

22. Pikarsky E, Porat RM, Stein I, Abramovitch R, Amit S, Kasem S, Gutkovich-Pyest E, Urieli-Shoval S, Galun E, Ben-Neriah Y. NF-[kappa]B functions as a tumour promoter in inflammation-associated cancer. Nature 2004; 431: 461-466.

23. Tsatsanis C, Androulidaki A, Venihaki M, Margioris AN. Signalling networks regulating cyclooxygenase-2. Int J Biochem Cell Biol 2006; 38: 1654-1661.

24. Kim HJ, Hawke N, Baldwin AS. NF-kappaB and IKK as therapeutic targets in cancer. Cell Death Differ 2006; 13: 738-747.

25. Galluzzi L, Senovilla L, Zitvogel L, Kroemer G. The secret ally: immunostimulation by anticancer drugs. Nat Rev Drug Discov 2012; 11: 215-233.

26. Chang YF, Chuang HY, Hsu CH, Liu RS, Gambhir SS, Hwang JJ. Immunomodulation of curcumin on adoptive therapy with $\mathrm{T}$ cell functional imaging in mice. Cancer Prev Res 2012; 5: 444-452.

27. Chuang HY, Chang YF, Liu RS, Hwang JJ. Serial low doses of sorafenib enhance therapeutic efficacy of adoptive $\mathrm{T}$ cell therapy in a murine model by improving tumor microenvironment. PLoS One 2014; 9: e109992.

28. Enzler T, Sano Y, Choo MK, Cottam HB, Karin M, Tsao H,
Park JM. Cell-selective inhibition of NF-kappaB signaling improves therapeutic index in a melanoma chemotherapy model. Cancer Discov 2011; 1: 496-507.

29. Dong QG, Sclabas GM, Fujioka S, Schmidt C, Peng B, Wu T, Tsao MS, Evans DB, Abbruzzese JL, McDonnell TJ, Chiao PJ. The function of multiple IkappaB : NF-kappaB complexes in the resistance of cancer cells to Taxol-induced apoptosis. Oncogene 2002; 21: 6510-6519.

30. Li F, Sethi G. Targeting transcription factor NF-kappaB to overcome chemoresistance and radioresistance in cancer therapy. Biochim Biophys Acta 2010; 1805: 167-180.

31. Patel MR, Chang YF, Chen IY, Bachmann MH, Yan X, Contag $\mathrm{CH}$, Gambhir SS. Longitudinal, noninvasive imaging of T-cell effector function and proliferation in living subjects. Cancer Res 2010; 70: 10141-10149.

32. Hirsch HA, Iliopoulos D, Struhl K. Metformin inhibits the inflammatory response associated with cellular transformation and cancer stem cell growth. Proc Natl Acad Sci USA 2013; 110: 972-977.

33. Breart B, Lemaître F, Celli S, Bousso P. Two-photon imaging of intratumoral CD8 $+\mathrm{T}$ cell cytotoxic activity during adoptive $\mathrm{T}$ cell therapy in mice. J Clin Invest 2008; 118: 1390-1397.

34. Tong CC, Kao J, Sikora AG. Recognizing and reversing the immunosuppressive tumor microenvironment of head and neck cancer. Immunol Res 2012; 54: 266-274.

35. Bracci L, Schiavoni G, Sistigu A, Belardelli F. Immunebased mechanisms of cytotoxic chemotherapy: implications for the design of novel and rationale-based combined treatments against cancer. Cell Death Differ 2014; 21: 1525.

36. Ramakrishnan R, Assudani D, Nagaraj S, Hunter T, Cho HI, Antonia S, Altiok S, Celis E, Gabrilovich DI. Chemotherapy enhances tumor cell susceptibility to CTL-mediated killing during cancer immunotherapy in mice. J Clin Invest 2010; 120: 1111-1124.

37. Alizadeh D, Trad M, Hanke NT, Larmonier CB, Janikashvili N, Bonnotte B, Katsanis E, Larmonier N. Doxorubicin eliminates myeloid-derived suppressor cells and enhances the efficacy of adoptive T-cell transfer in breast cancer. Cancer Res 2014; 74: 104-118.

38. Reagan-Shaw S, Nihal M, Ahmad N. Dose translation from animal to human studies revisited. FASEB J 2008; 22: 659661.

39. Sica A, Schioppa T, Mantovani A, Allavena P. Tumourassociated macrophages are a distinct M2 polarised population promoting tumour progression: potential targets of anti-cancer therapy. Eur J Cancer 2006; 42: 717-727.

40. Chen W. IDO: more than an enzyme. Nat Immunol 2011; 12: 809-811.

41. Grivennikov SI, Karin M. Dangerous liaisons: STAT3 and NF-kappaB collaboration and crosstalk in cancer. Cytokine Growth Factor Rev 2010; 21: 11-19.

42. Wang C, Zhou Q, Wang X, Wu X, Chen X, Li J, Zhu Z, Liu 
$\mathrm{B}, \mathrm{Su} \mathrm{L}$. The TLR7 agonist induces tumor regression both by promoting $\mathrm{CD} 4+\mathrm{T}$ cells proliferation and by reversing $\mathrm{T}$ regulatory cell-mediated suppression via dendritic cells. Oncotarget 2014; 6: 1779-1789. Doi: 10.18632/ oncotarget. 2757 .

43. Trinchieri G. Interleukin-12: a proinflammatory cytokine with immunoregulatory functions that bridge innate resistance and antigen-specific adaptive immunity. Annu Rev Immunol 1995; 13: 251-276.

44. Slaney CY, Kershaw MH and Darcy PK. Trafficking of T cells into tumors. Cancer Res 2014; 74: 7168-7174

45. Mahmoud SM, Paish EC, Powe DG, Macmillan RD, Grainge MJ, Lee AH, Ellis IO, Green AR. Tumorinfiltrating CD8+ lymphocytes predict clinical outcome in breast cancer. J Clin Oncol 2011; 29: 1949-1955.

46. Wolf D, Wolf AM, Rumpold H, Fiegl H, Zeimet AG, Muller-Holzner E, Deibl M, Gastl G, Gunsilius E, Marth C. The expression of the regulatory $\mathrm{T}$ cell-specific forkhead box transcription factor FoxP3 is associated with poor prognosis in ovarian cancer. Clin Cancer Res 2005; 11: 8326-8331.

47. Dmitrieva RI, Revittser AV, Klukina MA, Sviryaev YV, Korostovtseva LS, Kostareva AA, Zaritskey AY, Shlyakhto EV. Functional properties of bone marrow derived multipotent mesenchymal stromal cells are altered in heart failure patients, and could be corrected by adjustment of expansion strategies. Aging (Albany NY) 2015; 7: 14-25.

48. Mathieu A, Remmelink M, D’Haene N, Penant S, Gaussin JF, Van Ginckel R, Darro F, Kiss R, Salmon I. Development of a chemoresistant orthotopic human nonsmall cell lung carcinoma model in nude mice: analyses of tumor heterogenity in relation to the immunohistochemical levels of expression of cyclooxygenase-2, ornithine decarboxylase, lung-related resistance protein, prostaglandin E synthetase, and glutathione-S-transferase-alpha (GST)-alpha, GST-mu, and GST-pi. Cancer 2004; 101: 1908-1918.

49. United Kingdom Coordinating Committee on Cancer Prevention Research's Guidelines for the Welfare of Animals in Experimental Neoplasia. Br J Cancer. 1988; 58: 109-113. 